english version 1.1 | november 2013

\section{\#MacroMesoMicro.}

Systemic Territory Framework from the perspective of the Social Innovation

Is a project by Dr. Igor Calzada, Adolfo Chautón y Domenico Di Siena.

Its content has been developed entirely using open software programs (scribus, inkscape, gimp, circos.ca) and own or license creative commons resources (flickr, nounproject.org)

Cover image: Thingvellir Icelandic Old Parliament by lgor Calzada

ISBN:

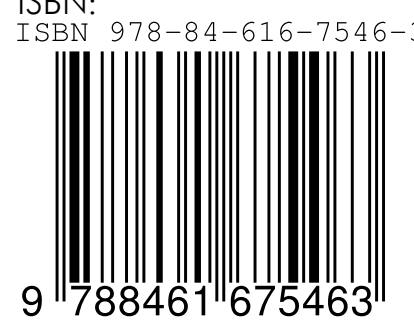

Under a Creative Commons License [Atribution - Share Alike].

\section{(ㄷ)(i) (2)}





\section{INDEX}

\section{ABSTRACT}

\section{PROLOGUE:}

THE CONCEPT OF TERRITORY FROM THE PERSPECTIVE OF SOCIAL

INNOVATION.

Dr Igor Calzada

\section{OPERATIONAL APPLICATION:}

PAG. 50

PAG. 8

WORKSHOP: INVIGORATION AND INTERVENTION.

Adolfo Chautón

BIBLIOGRAPHICAL REFERENCES.
PAG. 51

\section{EXPLORATORY METHODOLOGY:}

PAG. 18

HOW TO OBSERVE, EXPLORE AND TRANSFORM TERRITORIES.

Dr lgor Calzada \& Adolfo Chautón
A.- OBSERVING TERRITORIES (ROUTE MAP)
B.- EXPLORING TERRITORIES (MAKING-OFF)
C.- TRANSFORM TERRITORIES (WORKSHOP)

\section{ESTRATEGIC CONTENT:}

PAG. 25

SYSTEMIC TERRITORY FRAMEWORK FROM THE PERSPECTIVE OF SOCIAL

INNOVATION.

A.- \#MACRO APPROACH:

\#URBS + \#CYBER+\#CIVITAS + \#POLIS = \#DEMOS

Dr. Igor Calzada

PAG. 33

B.- \#MESO APPROACH:

EXPLORING THE \#BLACKBOX

Dr. Igor Calzada | Domenico Di Siena | Adolfo Chautón

C.- \#MICRO APPROACH:

\#HAND+\#MIND+\#SOUL+\#HEART=\#OPEN DNA

Adolfo Chautón 


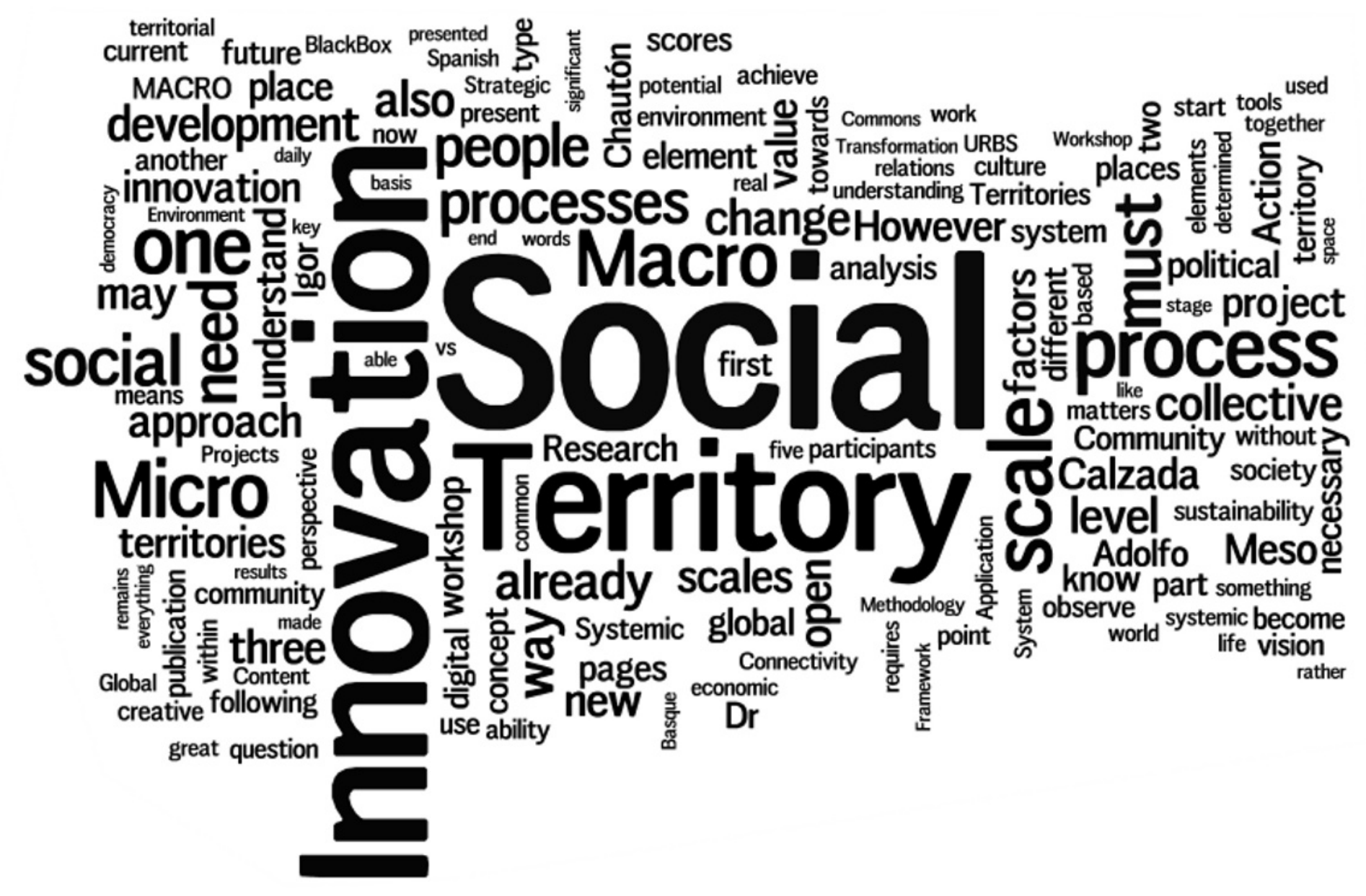


The concept of TERRITORY from the perspective of SOCIAL INNOVATION

@icalzada 


\section{THE CONCEPT OF TERRITORY FROM THE PERSPECTIVE OF SOCIAL INNOVATION}

\section{Dr. Igor Calzada}

The place matters ${ }^{1}$. We were born there, have been living and working there, entered there and exited from there. Places are an object of observation from the outside while we experience them from the inside. Calvino may have envisioned the city ${ }^{2}$ as a place that is entered and should be exited (Subirats, 2011 ), but before anything else, we are talking about places, where the relationships among the actors configure the decisions that are made regarding the specific place. A place is the most ethnographic level of observation of relational territorialisation. However, do we really know how territories behave? Can we really observe in practise the notion of the Network Territory? (Haesbaert) How does the dynamic concept of a territory fit and juxtapose with that of a network? And, how can this notion of the Network Territory change the assumptions we make about the City, Nation, and State?

The EU is supporting many programmes aimed at funding projects under the common denominator of Social Innovation. Innumerable networks of partners and agencies are developing speech that has little to do with the deep causes of the global crisis affecting us. However, what can also be observed is that some territories are putting all their efforts, thanks to the common work of public, private, and civil agents, into restructuring the post-crisis economic and social system (Calzada, 2012). Nevertheless, can we observe and see what is occurring in these places and territories? How are we supposed to observe

1 Independently of the particular and peculiar vision that each individual may attribute to a flat (Friedman or hilly (Florida) space, place matters. In subsequent sections, we will see the connection that the vision of Network Territoriality, at the local/global level, generates very diverse visions in terms of proximity and distance and flatness and elevation that we may observe and explore in the Territory. We will discuss these visions later. Right now, Professor Heather Haveman's quote is interesting regarding the connection between entrepreneurship geography and the importance of place and physical space: "As spatial barriers decline, competition expands geographically (space matters less) and the site of production becomes more relevan place matters more

2 | These two articles by Joan Subirats are of special interest

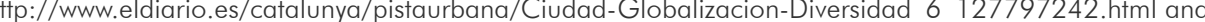
http://medialab-prado.es/mmedia/8338/view. 
those big black boxes with input and output but with an unknown and hardly explainable process? How can we apply hermeneutics to the socially innovating processes in the networked territories at any scale? What tools should we use for this observation? What tools do we want and can we use to intervene? What effect do we ultimately want to have?

All these elements may require a systemic vision. This adjective has often been used following management trends, losing its meaning in the hands of those who do not understand it. Systemic must be understood here in a cybernetic sense. It is what Gregory Bateson ${ }^{3}$ could deliver to us through the systemic, multi-disciplinary, and cybernetic path that Social Innovation requires. As "the map is not the territory and the name is not the object that is named"4, it is a systemic and multi-disciplinary approach ${ }^{5}$ that links the two currents of Social Innovation in a coherent way: we are referring to, on the one hand, the more academic approach, with a social justice dimension, aligned towards the Territory and Social Economy (Moulaert, 2013) and, on the other hand, the more practitioner and policy-making approach, championed by the third-way labour school of thought of the Young Foundation, Nesta and DEMOS (Mulgan, 2007). These two trends are currently defining a "serious" line with respect to the great "boom" of a plethora of consultancies, projects, and counsellors that have emerged with the support of EU project funding. The objective of this publication is thus to suggest taking a step back to achieve some impulse and present a Territory Systemic Framework from Social

Innovation. Conducting this investigation with the same great style as Williams ${ }^{7}$ in his amazing \#Keywords is a fundamental task. Looking for the semantic meaning and avoiding getting lost in the clichés appear to be some basic requirements, as social transformation and democracy are already words that are currently associated with indignation ${ }^{8}$ more than with hope. Thus, the 3 | Bateson, Gregory (1972), Steps to an ecology of mind: Collected Essays in Anthropology, Psychiatry,

4 | Coined by Bateson himself, influenced by Korzybski.

5 | This concept has also lost its meaning. It was used in an illustrative way by Frans Johansoon in his wellknown Medici Effect.

6 | http://www.emes.net/uploads/media/4EMES detailedprogram v2.pdf

7 | http://graduateglobalissues.files.wordpress.com/2012/08/raymond-williams-keywords.pdf

8 | http://sociologosplebeyos.com/2012/12/19/la-izquierda-ha-desaparecido-manuel-castells methodological approach that is implemented here is careful with the \#Keywords it uses. We mixed elements from (a) Action Research as a suggestion for the investigation methodology, the way to observe (b) the Territory from the viewpoint or paradigm of (c) Social Innovation. That is to say, in a Derridan sense, that we de-constructed ${ }^{9}$ the Territory into three scales to be able to observe, understand, and implement social transformations.

It is necessary to progress gradually and to expose the meaning of the object to be designed in a globalway between@icalzada, @adolfochauton and @urbanohumano. The publication consists of three main structural parts: The first part presents the Exploratory Methodology, the second addresses the Strategic Content, and the third concerns the Operational Application. The publication starts with this introduction and ends with the conclusions. This publication was presented in an ad-hoc manner by the three aforementioned authors, as an open-source publication and with an ISBN, to be presented, debated, and revisited under the auspices of the \#OPENMADRID ${ }^{10}$ Summer School in Madrid, MediaLab Prado and Juan Carlos University, June 24-26, 2013.

The authors believe that the moment is ideal, given the present economic situation affecting the Spanish State with an accelerated recession, to suggest a non-unifying but rather diverse viewpoint, which allows for sensing, in a participative and dialectic way, the future of the various territories. The study considers their precious idiosyncrasy to settle in it and overcome and channel the serious situation and thus to reformulate from their origin the social, economic, cultural, and political structures. This statement means that this proposition is not sterile and does not represent a type of institutional or political marketing disguise. Thanks to exploratory intuition, this study suggests the cultivation of a collective intelligence (which exists, as has been demonstrated by events such as \# 15M and \#indignados, which have been analysed at length by intellectuals we follow, such as Bauman ${ }^{11}$ and

9 | Deconstruction is a way of thinking that often criticizes, analyses, and deeply revises words and their concepts.

10 | http://openmadrid.org/talleres/macro-meso-micro-innovacion-social-territorio

11 | http://politica.elpais.com/politica/2011/10/17/actualidad/1318808156_278372.html 
Castells ${ }^{12}$ ). This collective intelligence must understand how to take advantage of its uniqueness as a Territory, which is where Social Innovation and the Spanish State may not fit in at all but ${ }^{13}$ is the scheme of coexistence that is inherent to a unity but also foreign to the notion of a Territory-Network ${ }^{14}$. In that regard, this publication does not aim to examine the territorial model of the Spanish State. Instead, the normality with which, in places such as the United Kingdom, the potential modifications of the institutional, territorial, and political models that would affect its internal configuration ${ }^{15}$ are treated is surprising. All these considerations lead us to the following comment: Social Innovation must also be concerned with suggesting control over the changes in the material and social space conditions of the Territory. The type of Social Innovation that we present does not contradict any possibility of Social

Transformation but also does not act as a unifying and dogmatic ideology, as explained in the following quote ${ }^{16}$ :

"What good does it do Territories (States, Nations, Regions, Cities, Districts and Villages) to be proud of their past if they do not strive to be proud of their future?"

Which is completed by this quote ${ }^{17}$ :

"A Country (or Territory) is not going to look like what it remembers, but like what it is doing".

12 | http://www.ciabogas.com/2013/01/16/vamos-despacio-porque-vamos-lejos

13 | http://www.igorcalzada.com/will-socialinnovation-save-spain-hub-islington-london-uk http://socialenterprise.guardian.co.uk/social-enterprise-network/2013/jan/02/spain-enterpreneurseconomic-enterprise-cooperative

14 | Interesting Nation-Network Seminar, organized by Antoni Gutierrez-Rubí, where interesting issues and suggestions were formulated, from a political, social, and territorial point of view.
http://www.igorcalzada.com/congreso-nacion-red-de-la-nacion-a-la-comunidad-virtual-universitat-de-lleidacatalunya-19th-january-2013

15 We are referring to the sovereignty processes that are occurring in some places such as Scotland, where the future of the United Kingdom and Scotland is debated, including in high-level scientific discourse.

These processes serve as examples of peaceful democracy and full citizen participation.
http://www.esrc.ac.uk/impacts-and-findings/our-research/future-of-uk-and-scotland/index.aspx 16 | Gabiña, J. (1998), Prospective and Organization of the Territory: Towards a Future Project.
Marcombo, Barcelona. Page 17. 17 | http://gara.naiz.info/paperezkoa/20130303/390639/es/Un-pueblo-no-va-pareciendo-que-recuerda-
In other words, we are considering the Territory as a unit that is susceptible to being objectified and that can provoke within itself a Social Transformation that will lead it towards its future. What we know now is that the future of Territories is currently determined by two variables: their network-notion and their value of commons. The Territories that are able to mingle with the collective intelligence that is strategically aligned with the understanding of the Territory-Network and Common Welfare will be in a better position to undertake some real processes of Social Innovation within themselves. In that regard, not all territories start from the same evolutionary principle. We could thus mention the division between the Global North and the Global South ${ }^{18}$ to incorporate a working hypothesis that will accompany the publication for the start: There is a great paradox suggesting that developing countries (Global South?) may be objectively more inclined to really implement processes of Social Innovation in societies, with a potential for human and social development that would be more significant than in developed countries that already start from growing urbanisation and apparent climatic unsustainability levels. The hypothesis would be, would not Maslow still have something to say about the evolution and the stages/contexts of complete Social Innovation? The question that would remain would be, consequently, which policies, projects, and agents/people should be promoted within the Territories? And what role do creative atmospheres or ecosystems play ${ }^{19}$ ?

Let us then answer three questions: What? Why? How? That is to say, Territory, Innovation, and Action Research:

\section{A.- Territory}

Let us define Territory ${ }^{20}$ :

$18 \mathrm{http} / /$ www.ateneonaider.com/articulos-opinion/manu-fernandez/la-silenciosa-urbanizaci\%C3\%B3n-

19 | Mulgan's Bees and Trees metaphor may remain valid in understanding how they function.

20 I In that regard, I would like to contribute to the theme of the territory a debate that already seems to be a classic among techno-sceptics and pro-technology groups. It is necessary to have this debate because the position we will defend will consist in denying that everything that is networked is digital; however, saying tha the territory is restricted to something physical is not clear either. Thus, the \#MACR \#C ES key, to understand the Territory as an object of analysis. I was inspired by the UPV-EHU forum that was held on May
3,2013 in Bilbao, where this debate between people from the institutional and political sphere and the

academic world was initiated: http://www.igorcalzada.com/euskal-hiriak-orekak-desorekak-ehugunea-
13 feb-y-3may-2013-bilbao. 

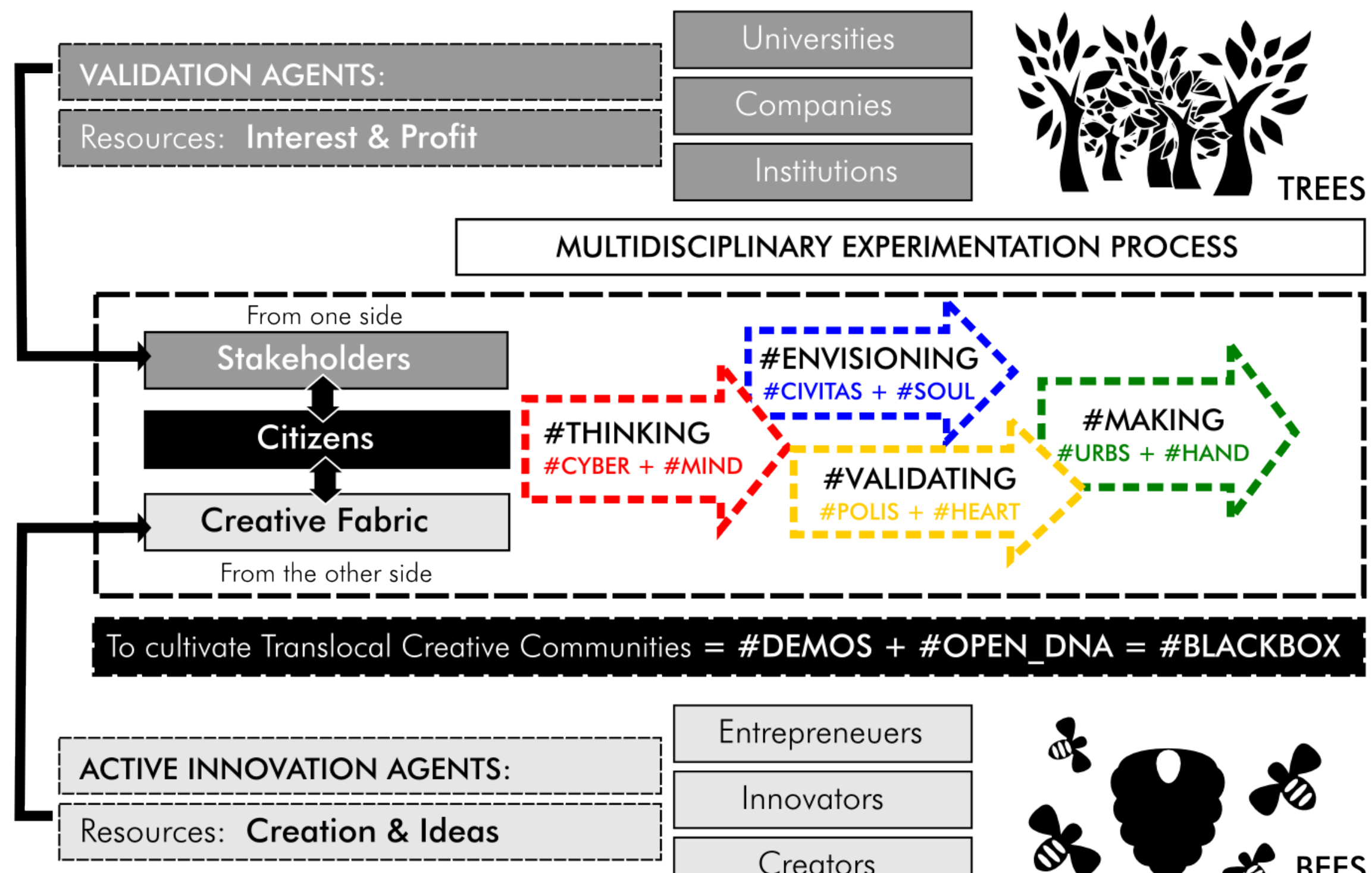

TREES

MULTIDISCIPLINARY EXPERIMENTATION PROCESS 


\section{TERRITORY $=($ LAND + IDENTITY)*NETWORKS $($ physical + digital + social $)$}

The What, the place, the space, the Territory. The material and biological aspect but also the intangible and cultural. Land + Identity. All Territories are different, even when they have the same socio-demographic radiography. As a comparison, the following quote reinforces the comment by Brazilian author Haesbaert $^{21}(2011)$ :

"Territorialising also means, nowadays, building or controlling the flows or networks, and creating symbolic references in a moving space, in and for the movement".

This quote suggests that the structuring of a Networked Society (Castells, 2013 ) is not necessarily synonymous with de-territorialisation because, in general, this process entails new territorialisation processes. The fundamental element in the formation of territories in these territorialisations, to the point of blending with them, is the network.

However, in addition to the networks that will be exposed in their \#Macro \#Cyber scale and their \#Micro \#Mind scale, there is the land, which is tangible in the \#Macro \#Urbs and \#Micro \#Hand. The relations of interaction between the systems occur in the middle, in parallel with the \#Macro and \#Micro scales, that is to say in \#Macro \#Civitas scales, \#Micro \#Soul, \#Macro \#Polis, and \#Micro \#Heart. The first interactions are sociocultural, and the second ones are socio-political.

But what has happened to the object, both the Territory and Land, over the past century? We will adopt the brilliant approach of one the most outstanding geographers at the moment, David Harvey (2012):

\section{1 | http://www.unc.edu.ar/extension-unc/vinculacion/instituciones-sociales-y-salud/acciones-} realizadas/actividades-realizadas/2010/seminario-extensionista-aportes-de-la-epidemiologiacomunitaria/unc-seu-mito-desterritorializacion.pd

22 | Adopting the original model of innovation by Schumpeter to describe the change in cycle and the need for Social Innovation to achieve social transformation and resilient transition is as appropriate and inspiring as using this musical number to illustrate in university-level classes of Mondragon Unibertsitatea What is innovation? (in this case, technological and a posteriori social) The Buggles - Video Killed The cases.
"Over the past three centuries, during which capitalism rose, the speed and scope of the creative destruction ${ }^{22}$ of the Territory has increased dramatically".

We thus come to the What for. We cannot deny that beyond identifying an entity of analysis, the Territory is a systemic and interdependent set. As Harvey ${ }^{23}$ explains in depth, from climate change to cyber-security, from poverty to pandemic, from food technologies to fracking, and for everything related to the intellectual property of living organisms and their public and private use, the role of politics and social movements, scientists, engineers, and other policy-making experts must provide an answer in an open and transparent conversation with citizens. However, as Bauman also explains (2011), when referring to the necessary collective intelligence to move towards another stage, Social Innovation does not occur massively; it is an experimental and selective process, with constant interaction between bees and trees ${ }^{24}$.

\section{B.- Social Innovation}

At this point, the \#Macro and \#Micro are blended to achieve an intermediate synthesis: \#Meso, which is the scale where what Mintzberg called "The Black Box" in the Strategy occurs. Thus, when talking about Social Innovation, we must distinguish Territory from Environment or Ecosystem (Mulgan, 2007), primarily because in \#Meso, the relations that can or cannot transform the social relations of the five systems are built until the \#Macro scale (via Policies and Projects) and the \#Micro scale (via Projects and People) are reached.

The aim of this publication is to deconstruct the Strategic Content to achieve an Application Tool of the Territory from Social Innovation through an Exploratory Methodology that will follow the paradigm of Action Research.

23 A very interesting presentation in Athens by Professor Harvey about the role of social urban movements in the current crisis situation: http://www.youtube.com/watch? feature= player embedded\&v=XWb6 UvlwCU 24 I Illustration taken from page 220 of reference: Moulaert, F., MacCallum, D., Mehmood, A. and
Hamdouch, A., Calzada, I. (2013), International Handbook of Social Innovation. Social Innovation: Collective Action, Social Learning and Transdisciplinary Research. Cheltenham: Edward Elgar. 
\#MACRO

[\#URBS $\mid$ \#CYBER $\mid$ \#CIVITAS $\mid$ \#POLIS $]=$ \#DEMOS

\#MESO

\#BLACKBOX

\#MICRO

[\#HAND | \#MIND | \#SOUL | \#HEART] = \#OPEN_DNA
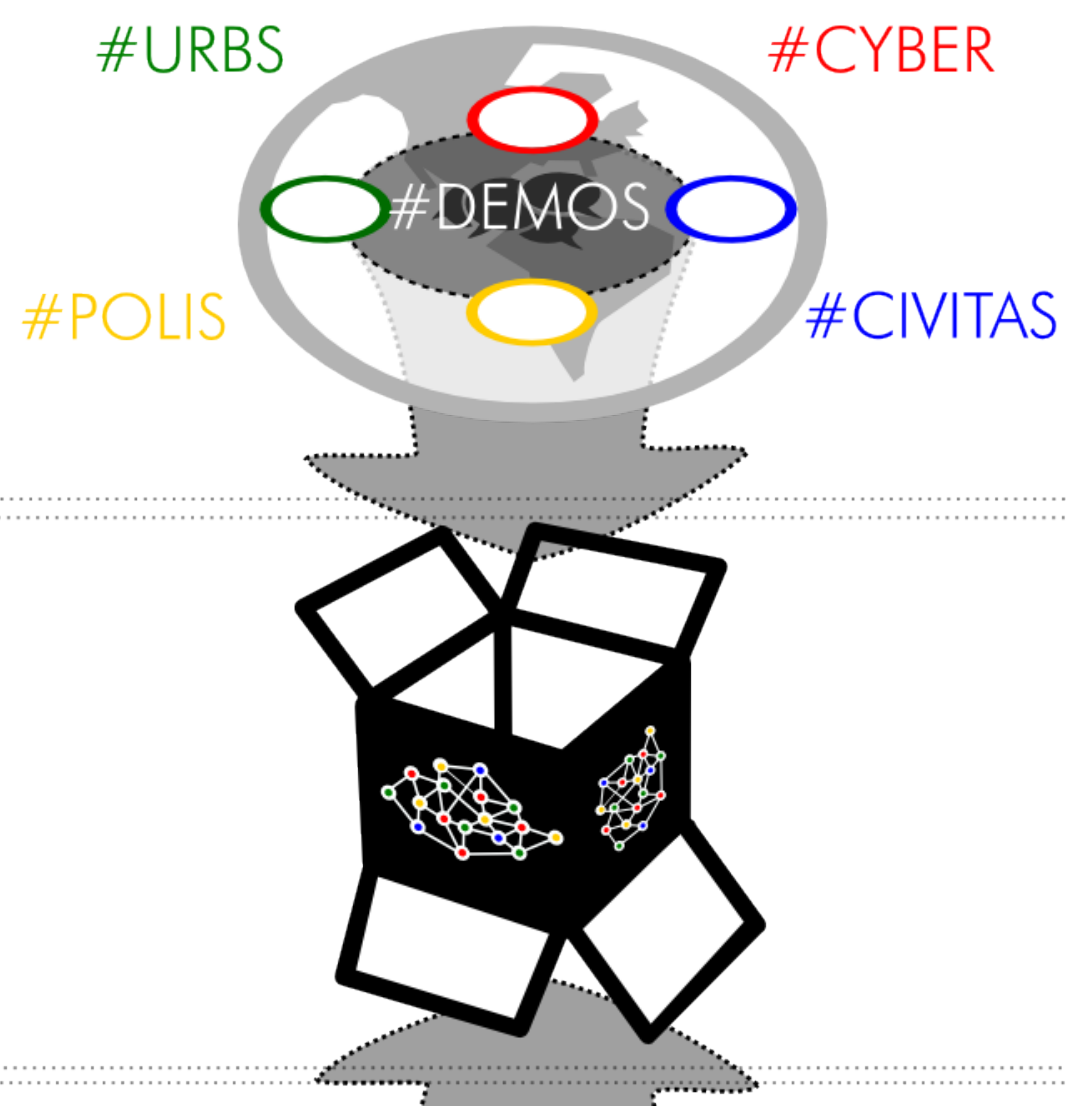

\#MIND

\#HAND

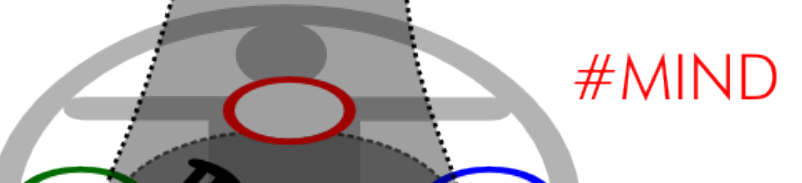

\#SOUL 


\section{C.- Action Research}

Without aiming to explain the methodological current of Action Research, we will develop a decalogue of key ideas before moving on to the Strategic Content. Among the various versions of Action Research ${ }^{25}$, we have considered Professor Yriö Engeström's Activity Theory ${ }^{26}$ to be one of the major contributions to this type of qualitative social investigation methodology.
25 | A current method known as Design Thinking, which comes from classic authors such as Peter Senge with his systemic learning and the fifth subject and more methodologically, the great contribution from Checkland

26 | http://www.helsinki.fi/cradle/activitysystem.htm
The ten key ideas are:

\section{1.- \#Territory as a \#Political \#Technology 27}

The three scales contain the assumption that there is a capacity to articulate and change through the coordinated action of a disparate collective intelligence.

\section{2.- \#Social-Innovation for \#Social Transformation}

We examine the 5 systems in depth and not as a symbolic and testimonial method of moving resources from one place to another.

\section{3.- \#Scope: EU? Spain? \#Regional perspective. \#Translocalism \& \#Multilevel.}

We are talking about Territory, not about borders. The administrative limits are sometimes a method to limit the Territory-Network, which is why the definition of being regional - with the meaning established by authors such as Herod (2011), Hall (2012) and Herrschel \& Tallberg, Bronfenbrenner ${ }^{28}$, Hughes \& Sadler ${ }^{29}$, and others - remains an unclear category but allows us to use spatial and temporal scales to understand and articulate the Social Innovation processes.

\section{4.- \#Territorial \#Scales}

This approach is how we will observe our territorial scales from a Social Innovation perspective:

\#Macro: Urbs/Cyber/Civitas/Polis.

\#Meso: Black Box. Social Innovation processes.

\#Micro: Hand/Mind/Soul/Heart.

27 | Formidable book by Stuart Elden.

28 | http://es.wikipedia.org/wiki/Urie Bronfenbrenner

29 | http://www.routledge.com/books/details/9780750640831/ 


\section{5.- \#Induction vs. \#Deduction: \#Transduction}

Induction never comes, and deduction always fades. As Simondon notes, maybe transduction, which uses, preserves, and amplifies the information that is available, is a good method of resolving the disparities in the spatial scale and the contradictions in the temporal one by rushing forward (inventing new dimensions).

\section{6.- \#Ideologies \& \#Politics lost in translation.}

Castells $^{30}$ affirms that the left has died (or at least has changed). The issue that arises is that throughout Social Transformation, the mechanisms of selforganisation and the ways of perceiving what common welfare encompasses and how it is managed are going through a major crisis.

\section{7.- \#Material \#Participation ${ }^{31}$ \& \#Dialectic.}

Because of the above comments, we may not draw on 19th century concepts to talk about inequalities. If ideology is in transition, its participation and dialectic will play at a more material level, where the resources, life conditions, and distribution will be first-class variables as long as we discuss Social Innovation. We talk about, to a certain extent, what comes to be discussed when the concept of commons is mentioned 32 . We will use this concept, based on the acknowledgement of Elinor Ostrom ${ }^{33}$, but it must be linked to hermeneutics at the \#Micro level.

\section{8.- \#Tensions \& \#Contradictions.}

The aim here is to search for contradictions and tensions, understand them at the \#Micro level, observe them at the \#Macro level, and strive to resolve them at the \#Meso level.

30 | http://sociologosplebeyos.com/2012/12/19/la-izquierda-ha-desaparecido-manuel-castells

31 | Noortje Marres.

32 | http://medialab-prado.es/article/video que es_el procomun

\section{9.- \#Temporal \#Scale: \#Twist.}

We have discussed the three spatial scales, \#Macro, \#Meso, and \#Micro. We still need to mention the temporal scale and its significance in understanding social innovation processes. Innovation suggests building for the future but also encompasses the logic of factors in their historical sequence, where by chance and on many occasions, similarities or at least explanation can be observed.

\section{0.- \#Everyday \& \#Ordinary \#Territory.}

We started this introduction with the statement "Place matters". It is true but not in its ever changing and urgent logic, which is often associated with the idea of innovation and creativity. We are in a state of transition, which behoves us to diminish at the right pace, think where and how value can be observed and how to contribute to saving resources but, before anything else, to be an ethnographer. Sit down and observe. Look, feel. Explore, from the streets, from the sidewalk, the cafeteria, the station, draw, talk, discuss...think. All these are ordinary and daily activities. These activities, in some institutional agendas, sound like the fear of the blank page, or in the Oteizian sense ${ }^{34}$, completely the opposite: purity and vacuum (huts, for its name in Euskera [Basque]). This result offers the possibility for anyone to become an aesthetic individual, artist, or artist of the ordinary. This situation is where the work by Sennet, The Craftsman; Jacobs and his strolls; and the seminal work by Robinson (2006) come together and take shape. And, we consider that Social Innovation must start from the assumption of the Territory and its people as the most daily, but also the most spectacular and least monotonous, stage. Maybe to discuss Social Innovation in territories at any scale, we need innovators-craftsmen, as Sennet says, strollers-walkers-explorers-ethnographers ${ }^{35}$ in Jacobs's style and, ultimately contextualisers of the ordinary, as Robinson frames it.

33 | http://nomada.blogs.com/ifreire/2009/10/elinor-ostrom-y-las-oportunidades-del-pro-comn-unpremio-nobel-para-la-gogs.com//freire/2009/10/ premio-nobel-para-la-gobernanza-de-sistemas-
complejos.html? utm_source=feedburner\&utm_medium =feed\&utm_campaign $=$ Feed\%3A+JuanFreire $+\% 28 \mathrm{~J}$
uan+Freire\%29

34 | https://www.youtube.com/watch? $v=$ PPvklyoNgol

35 | http://www.janejacobswalk.org/ 


\section{How to OBSERVE, EXPLORE and TRANSFORM TERRITORIES}

@icalzada + @adolfochauton 


\section{EXPLORATORY METHODOLOGY}
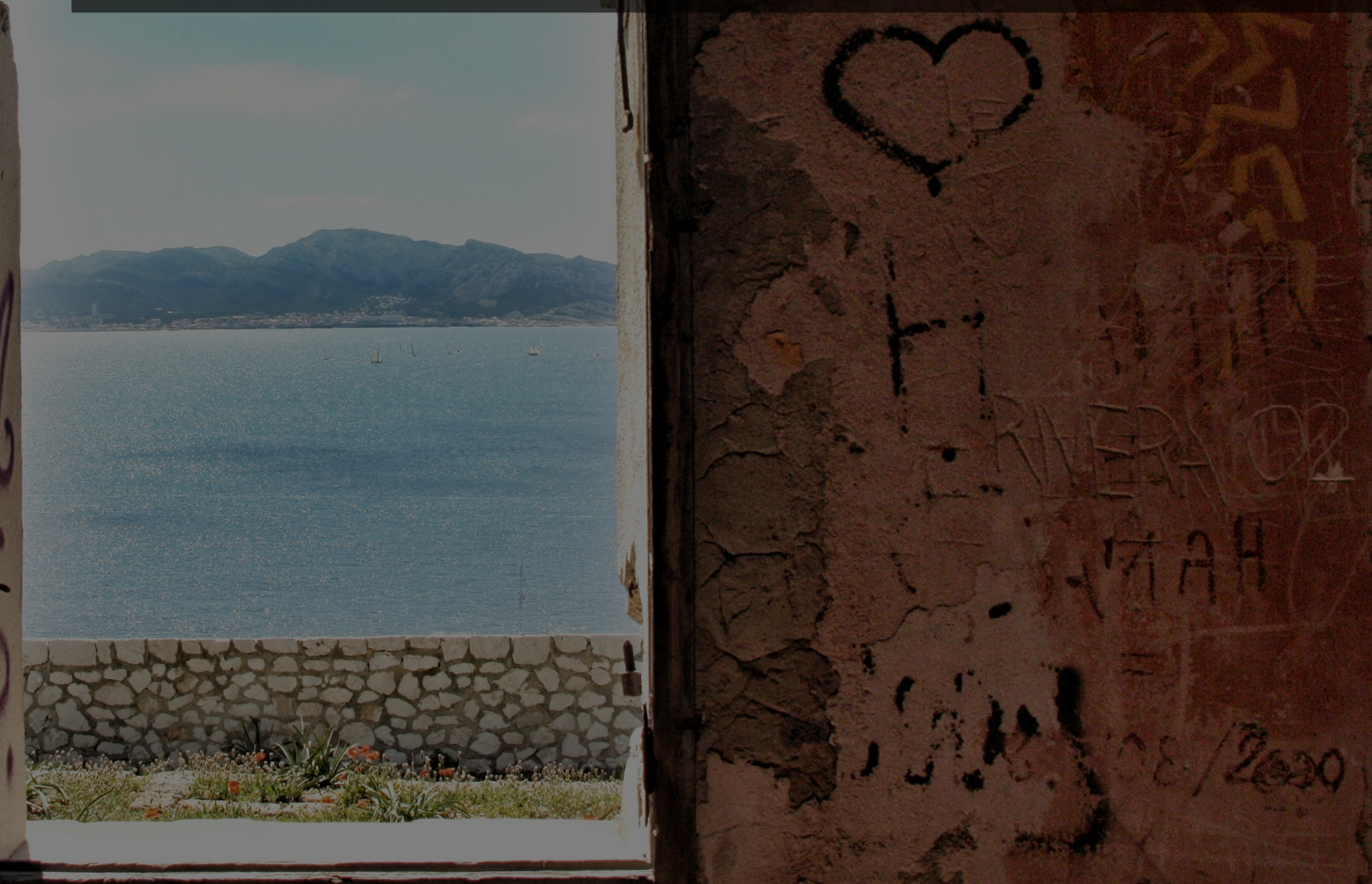
The methodology that was adopted is based on Action Research and specifically on Activity Theory. The division of spatial scales, \#MACRO, \#MESO, and \#MICRO, is necessary to make the intervention in Social Innovation Projects operational. This section on Exploratory Methodology is completed by one on Strategic Content and another on Application Tools.

The Exploratory Methodology will now be presented in its three sequential stages:

\section{A.- Observing: ROUTE MAP.}

The following diagram illustrates the three scales and their composition. In the \#Macro and \#Micro cases, the scales are divided into five Systems that will be presented in Section 2.1 and 2.2, respectively. The \#Meso scale receives a specific treatment because it is the sum of the analysis via the workshop, where the participants diagnose in the dark and unknowingly the BlackBox made by People, Projects, and Policies.

Once the \#Macro and \#Micro scales are revealed with all five Systems and 12 Factors, the remaining analysis will be conducted on the \#Meso scale, where some aspects of the two scales will be considered jointly.

\section{B.- Exploring: MAKING-OFF}

During the intervention stage in the workshop, the mediator will serve a double function: (a) allowing the participants to become familiar with the five Systems and the 12 Factors corresponding to \#Macro and \#Micro and (b) moving on to the second step of the workshop, by performing a diagnosis to explore in a constant way what the \#BlackBox contains from \#Macro to \#Micro and vice versa. We consider that this process is a very important transductive process that allows the participants to become familiar with the Systemic Framework, creating their own specific analysis that corresponds to an Agent, a Project, or a Social Innovation Policy in the Territory.

\section{C.- Transform: WORKSHOP.}

As a qualitative method of participative observation based on Action Research, we have suggested applying the Systemic Workshop in groups limited to 15 people. The workshop is a complex process of interwoven and disparate information that must be organised in a collective manner, with the mediator's help. The questions are open-ended and produce diverging answers among the participants, which must be collected as the result of the analysis.

We consider that both the result of the analysis and the process itself represent a Social Transformation insofar as the participants are faced with a reality they know with tools that make non-daily questions emerge. The participants "can" transform the \#Macro scale insofar as they can affect their strategic decisions and as these may be materialised in the real world. They "can" also transform the \#Micro scale in the mental model of each participant.

As will be presented in section 2.2, \#Meso scale, and in section 3, Operational application, two tools were used in the workshop: one of input and one of output.

The Input tool involves a deep and rigorous methodological development of sources based on Action Research. We will mention four of these sources specifically:

1. Organic vision.

2. The Activity System Theory ${ }^{36}$.

3. Reflexive Transformative Design Process ${ }^{37}$.

4. The Business Model Generation ${ }^{38}$.

36 | http://www helsinki.fi/cradle/activitysystem htm http://www edu helsinki.fi/activity/people/engestro/ 37 | http://www.intechopen.com/books/industrial-design-new-frontiers/designing-disruptive-innovativesystems-products-and-services-rtd-process

38 | http://alexosterwalder.com/ http://www.amazon.com/Business-Model-Generation-Visionaries-

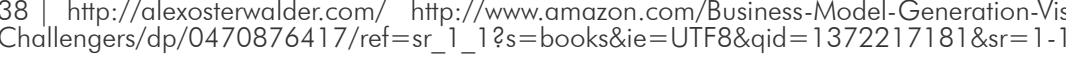




\section{\#MACRO}

[\#URBS | \#CYBER | \#CIVITAS | \#POLIS] = \#DEMOS

\#MESO

\#BLACKBOX

\#MICRO

[\#HAND | \#MIND | \#SOUL | \#HEART] = \#OPEN_DNA

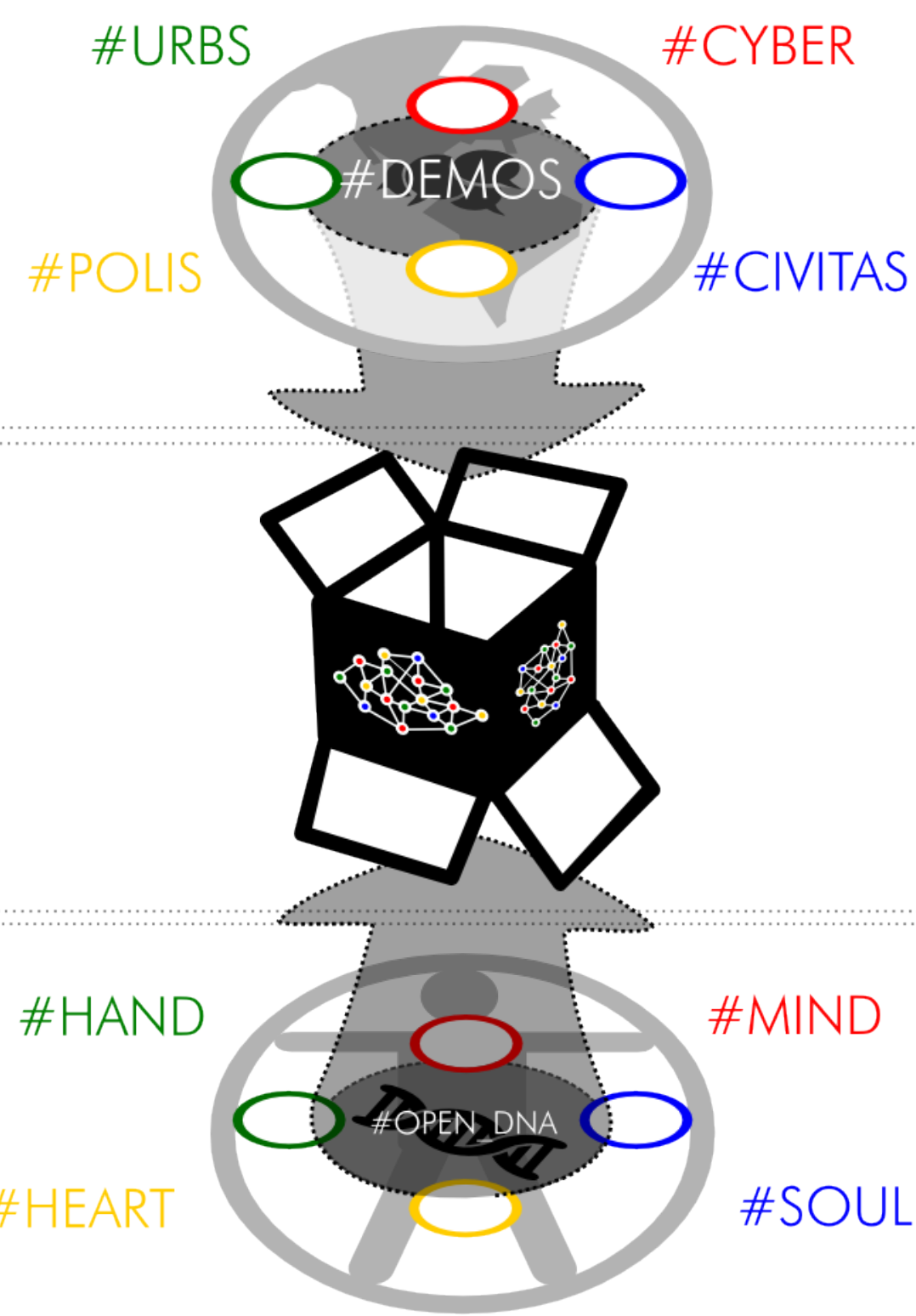




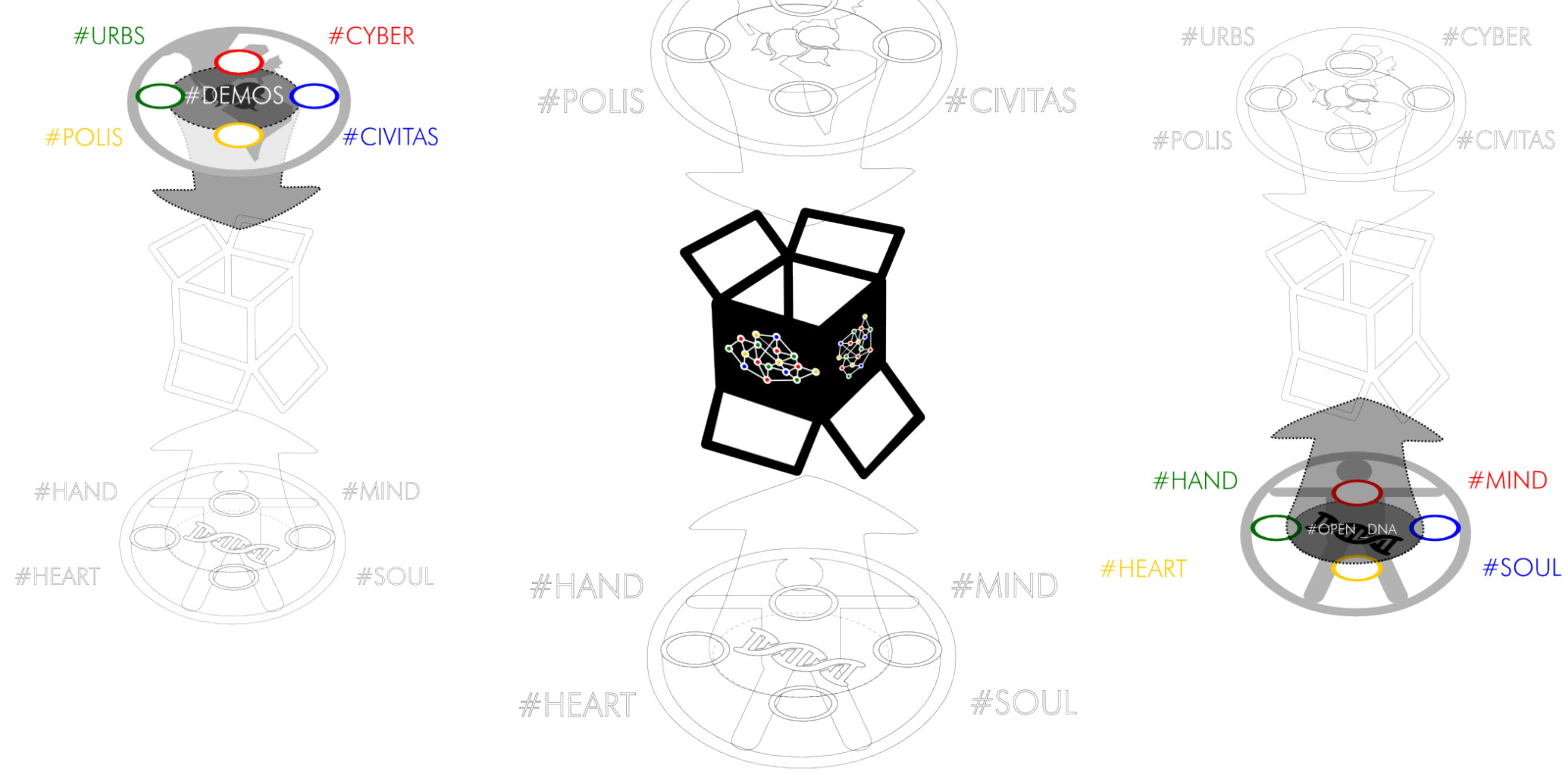


1 | ORGANIC VISION

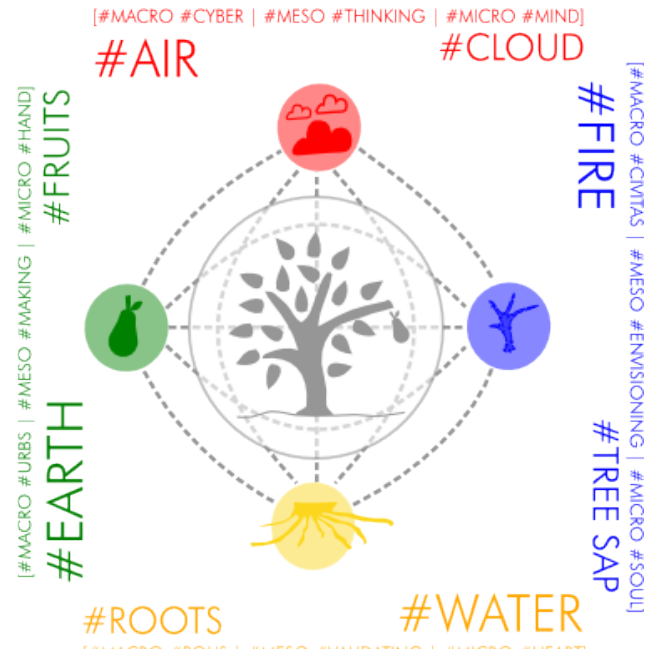

3 | REFLEXIVE TRANSFORMATIVE DESIGN PROCESS

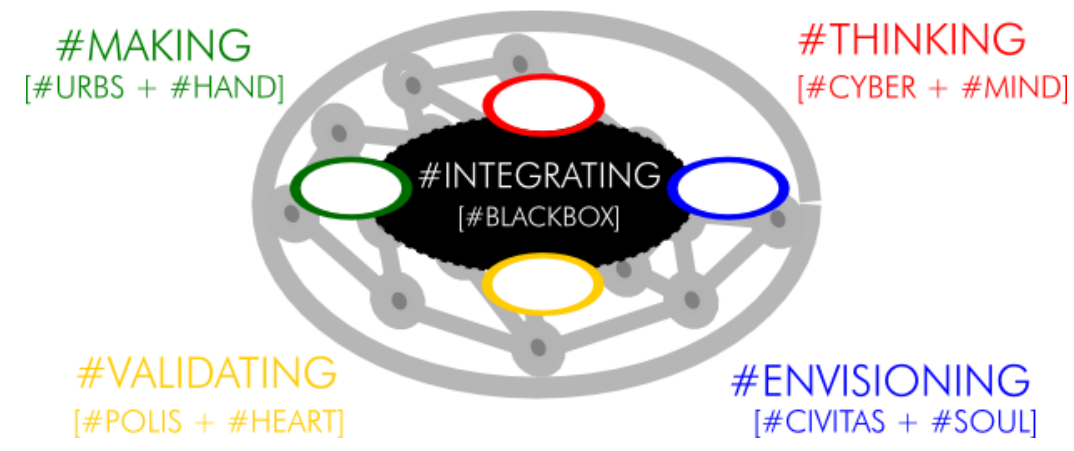

2 | THE ACTIVITY SYSTEM

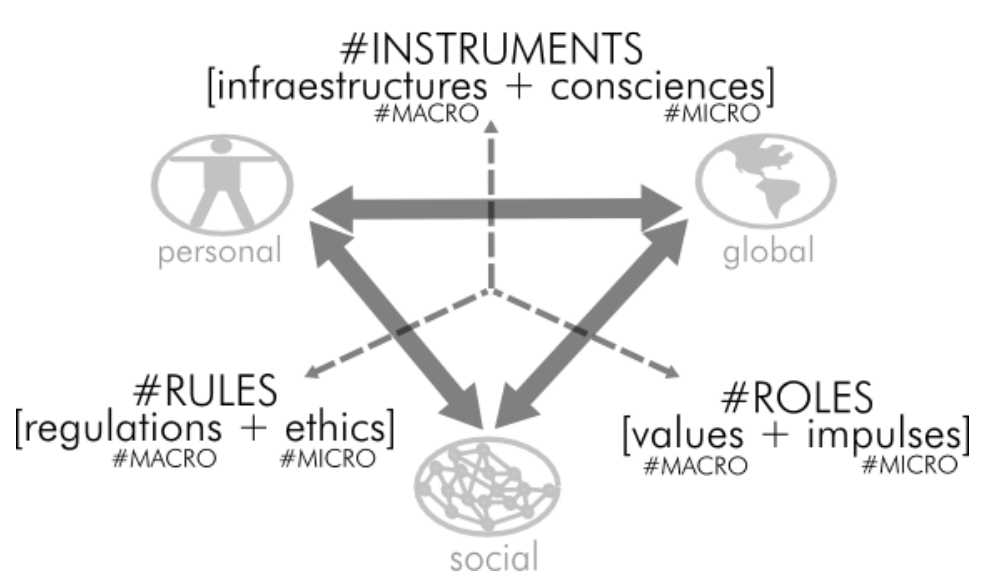

4 | BUSINESS MODEL GENERATION

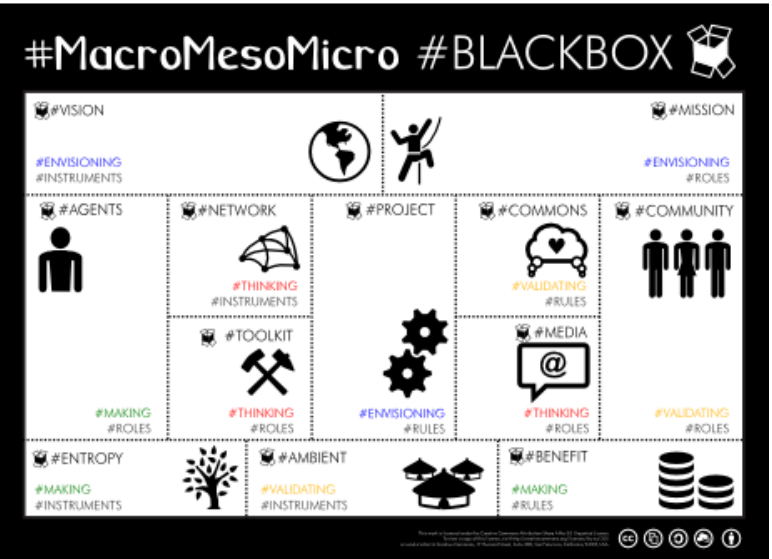




\section{SYSTEMIC TERRITORY \\ FRAMEWORK from the perspective of SOCIAL INNOVATION}

@icalzada + @urbanohumano + @adolfochauton 
STRATEGIC CONTENT 
\#HanlzanikHonaNaiz \#BeingTherelAmHere

\#EstandoAllíSoyAqui

JOSEBA SARRIONANDIA

\section{\#MACRO APPROCH}

\section{$[$ \#URBS $\mid$ \#CYBER $\mid$ \#CIVITAS $\mid$ \#POLIS] $=$ \#DEMOS}

\section{@icalzada}

We will now present the Strategic Content of the Systemic Framework. This reflective work is based on merging the results of publications 39 about "CityRegion: Basque Country, Dublin (Ireland) and Portland (Oregon-USA)" (Calzada, 2011) using@icalzada and @adolfochautón's intervention model. This merging yielded a permanent triangulation among @icalzada, @adolfochautón, and @urbanohumano.

This approach of the \#MACRO scale has been developed with the design of the aforementioned case studies (Basque Country, Dublin and Portland) and, perhaps more recently, by the scientific direction ${ }^{40}$ managed by @icalzada of Congreso Euskal Hiria - Basque City-Region 2012 celebrated in November 2012 in Bilbao, as the eleventh event organised every year by the Ministry of the Environment and Territorial Planning of the Basque government. The information can be found at the following domains:

http://www.euskalhiria.org, http://www.basquecity.org and

http://www.cityregions.org This line of investigation continues in the University of Oxford's Future of Cities Programme (UK) ${ }^{41}$.

39 | Calzada I. (201 la), Towards the Basque City? Comparative Territorial Benchmarking from Social Innovation: Dublin (Ireland) \& Portland (Oregon), Bilbao: Innobasque-Basque Innovation Agency.

Calzada, I. (201 1 b), ¿̇Hacia una Ciudad Vasca? Aproximación desde la Innovación Social, Vitoria-Gasteiz:

40 | http://www.igorcalzada.com/euskal-hiria-2012-kongresuaren-zuzendari-zientifikoa-bilbo-euskaldunajauregia-26-27-azaroak

41 +Info: http://www.cityregions.org @icalzada \& @Euskal Hiria 


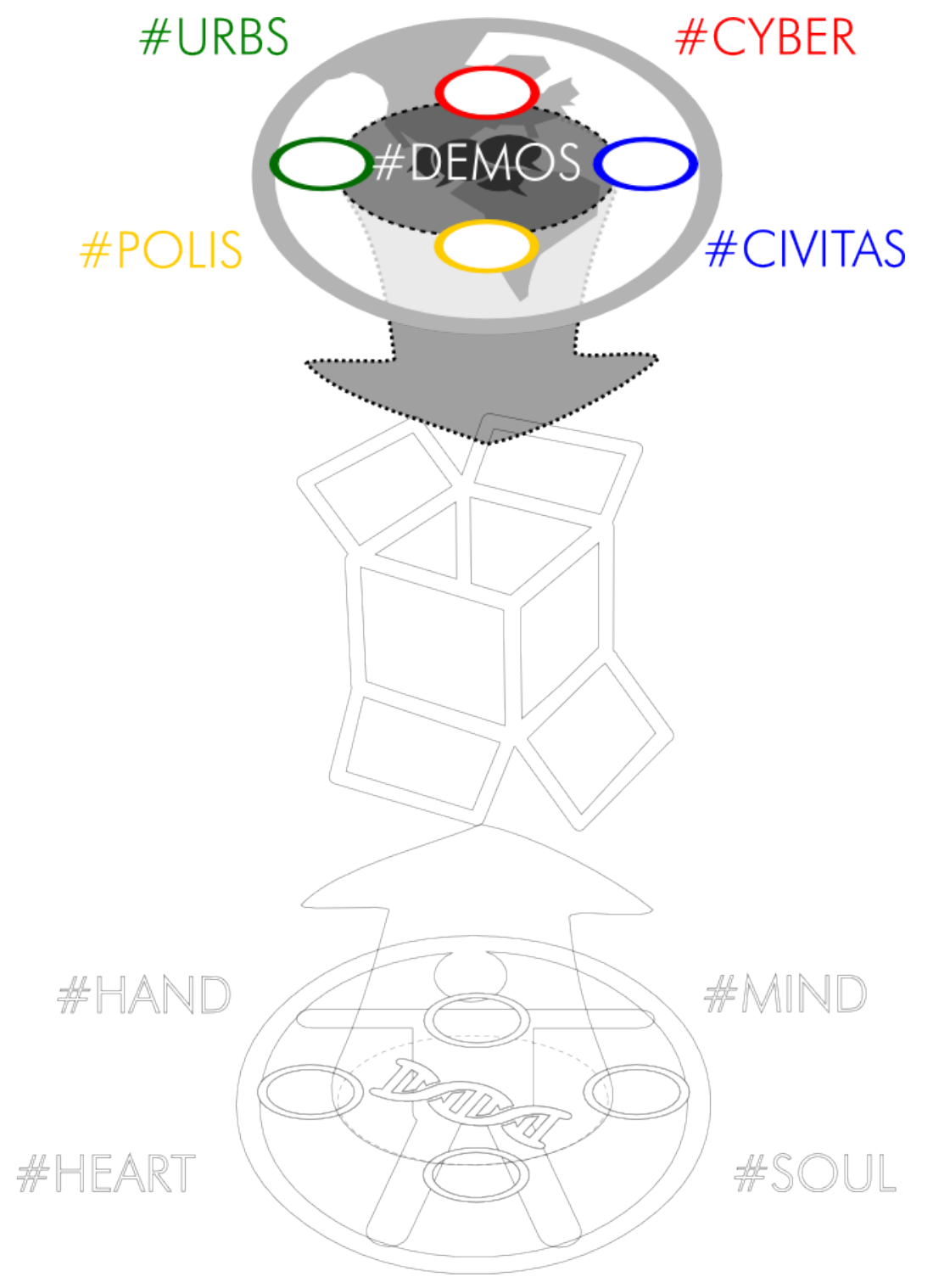

\#URBS: Technical, Physical \& Urban system.

1. Human Geography: Who?

People's material means or resources are closely related to the structure of needs and the unequal distribution of the consumption and production functions and power. Variables such as demographics (the aging of the population), different lifestyles, commuting, population density and land occupation, the relation to the urban environment, and the food supply condition the type of human geography. Maslow still offers significant contributions in this regard, insofar as we often observe a territory more in terms of productive output and through per capita income indexes than through parameters demonstrating the level of well-social justice to measure Social Innovation. Land occupation never occurs randomly, and it conditions people's lives at the same time as people condition material life on the entire territory.

2. Spaces of interaction ${ }^{42}$ : Sharing commons ${ }^{43}$ ?

We have moved from hacker ethics and the spirit of a society of information ${ }^{44}$ to those of coworking and hackathon. We have left factories and pavilions in industrial polygons empty and are now thinking about occupying them again with "creativity and innovation factories" or "LivingLabs" or "coworking" or "hubs". However, at the end of the day, what and who do we blend together again in those spaces of interaction? Museums ${ }^{45}$ that do not need to be only museums anymore? Libraries ${ }^{46}$ becoming mere conversations? What type of micro-urbanism are we creating? How do we manage it? What is the value of production/work? What are the limits of sharing and intellectual property? In

42 At the 2012 Euskal Hiria Congress, a round table was organized to discuss the topic of spaces of interaction: http://www.euskalhiria.org/2012/12/eh2012-debate-mesa-redonda-micro.html

43 | https://www.youtube.com/watch?feature=player embedded\&v=P6obOTf Els

44 | http://www.pekkahimanen.org/

45 | http://www.igorcalzada.com/cultura-20-videoconferencia-innovacampmediterrane-citilab-cornellabarcelona-22-23-5-09

46 | http://quartz.syr.edu/rdlankes/Publications/Journals/COLISFinal-v7.pdf 
short, what form does postdigitalism ${ }^{47}$ take, and what are the control/impulsion mechanisms of its production? What are the business/social models of the Spaces of Interaction in the Territory? How do the four typologies of the Spaces of Interaction behave (Anti-system-Gaztetxe [Youth house], Public-House of culture, Private-Business Cluster, and HybridPostmodern)? Can the regulation of how the space is used be a method of implementing a change in the Post-Crisis economic paradigm?

3. City-Network: Structure \& Resilient Polycentric Dynamic.

We already understand the effects of the acceleration and incessant accumulation of capital without limits (Jackson, 2009) and the resulting effects on urbanism (Boria, 2012) ${ }^{48}$. What we do not understand are the consequences related to the imminent threat of climate change (Hamilton, 2010). The effects of the peak-oil and global warming placed the Territory in a constant state of alarm whose parameters, through prospective scenario strategies, start to be designed in the most advanced places. How can we understand the consequences and the causes, the mitigation measures, or even the anticipation that can lead us to an acceleration of the dystopia process or, in contrast, initiate social innovation projects to create the transition era (Hopkins, 2012) ${ }^{49}$ ? As opposed to this discourse that no one appears to be against, silence remains regarding obligations and the competitiveness model. And when everybody says they agree, it definitely indicates that something is wrong. Here, concepts should be generating tension and structural contradictions to solve the issue in a systemic and interdependent way and not unilaterally. We also posit an unresolved dichotomy here: \#Degrowth vs. \#Competitiveness? ${ }^{50}$ In this dichotomy, maybe \#Post-growth should be transduced. What we cannot do in the present societal risk conditions (Beck, 1992) is to reproduce the system or be opposed to it.

47 | http://www.managementensalud.com.ar/ebooks/Geekonomia.pdf

48 Presentation by Professor Jordi Boria from UOC Ciudad:

http://www.euskalhiria.org/2012/12/eh2012-urbanizacion-especulativa-versus. html

49 | Presentation by the founder of Transition Networks in Tötness, which occurred virtually at the 2013

Euskal Hiria Congress: http://www.euskahiria org/search/labe

50 | http://www.euskalhiria.org/2012/12/eh2012-debate-mesa-redonda-macro.html
However, what structure must this new structure have? Regarding its centre and its periphery, the role of sprawl, the exhausted sustainability yields to resilience and what? Architects mention a City-Region mix ${ }^{51}$ such that economists can understand them because they talk about scaling governance and ultimately reducing overlaps. But where is the adequate balance between those polycentric and reticular structures and the classic variables of territory organisation, and now even micro-urbanism? In addition, Africa appears to be the answer to the problems of the Global North. In other words, Africa ${ }^{52}$ appears to be in a "privileged" position to apply Social Innovation in the Territory because it is primarily at a preliminary (or less accelerated) stage compared with the Global North and its developmentist ideology.

The point is thus to produce a Territory with a permanently balanced structure and dynamic. However, do we already understand how networked territories behave, their variables and the most favourable spatial configurations for the new, post-crisis and post-growth scenario that we should design and implement thanks to bottom-up participative territorial policies? Perhaps architects and economists should pay less attention to engineers and more to anthropologists and sociologists. The City-Network as part of the \#URBS of the \#MACRO Territory remains an unknown component that requires Action Research in every concrete case, by modelling, drawing, and, above all, understanding how Territories behave.

\section{\#CYBER: Relational System}

4. Physical Connectivity: Transports, Logistics \& Mobility.

In a recent publication ${ }^{53}$, an exhaustive analysis was conducted on the significance of the rationalisation ${ }^{54}$ of infrastructures for physical connectedness. We should not forget that we come from a developmentist

51 http://www.igorcalzada.com/download-here-basque-city-euskal-hiria-book-executive-summary

52 http://www.bbc.co.uk/news/world-africa-11823146

53 | http://www.cityfutures2009.com/PDF/32_Urena_JoseMaria.pdf

54 | http://elpais.com/diario/2010/05/20/economia/1274306410 850215.html 
paradigm that ravels the logic of disproportionate financial indebting to invest in often unnecessary infrastructures or those that are hardly maintained and funded with criteria of economic solvency and long-term environmental sustainability. The question stems from how to use existing infrastructures to support clean, inexpensive, and social modalities of connectedness, which is a constant balance between users and artefacts and not the opposite, as has been performed to date. Based on the previous comments, what would an adequate use of a territorial mobility system be, with its alternative options of business/social models?

5. Digital Connectivity: Unplug \& Plug and the new parameters of culture and communication code.

A debate is occurring together with dramatic changes in understanding technology in people's lives in territories. A question starts arising whether a cup of coffee and conversation has more value than a DM on Twitter or a post on Facebook. There are interesting, deeply hermeneutical visions, such as that of Turkle (2013), who suggests the following: "Alone Together: Why We Expect More from Technology and Less from Each Other". Zuckerberg is blended with Putnam and Bauman (2003). We start confusing, and sometimes are unable to interpret, the difference between Digital Social Networks (the famous Social Media) and Social Capital, that is to say the direct relation between the increase in digital communication flows through the incorporation of apps and the virality of networks and the level of trust and community value of those relations. This topic remains an interesting research issue. What is the true relationship between virtualisation and in-person communication in Digital Connectedness? To where is this digital culture leading us?

Faced with this potential cycle change in the digital connectedness manners, some,such as@urbanohumano, based on the prestigious and rigorous MIT work ${ }^{55}$ already refer to the concept of the Sentient City, where the Sensible Territory is some new space hybridising the virtual and the in-person in a new manner, going from Territory to Environment (Corsín) and already covering the three Contexts ${ }^{56}$ defined by Echeverría. For this reason, the Digital

55 | https://mitpress.mit.edu/books/sentient-city

56 | http://redaprenderycambiar.com.ar/javier-echeverria-tercer-entorno/
Connectedness factor can transform the Sensible Territory into an Environment and into a Social Innovation Ecosystem, where social transformations emerge, precisely at the \#MESO scale, in that black box that we cannot manage directly. McCollough's interesting study Ambient Commons (2013) should be mentioned, where the author paves the path to seeing this Territory not as an Environment but as an Environment Commons ${ }^{57}$.

It is certainly not by accident that we are experiencing knowledge of the \#Unplug ${ }^{58}$ value as well in urban public spaces and sometimes using the "Free No Wi-Fi Zone" to favour a cup of coffee and "Kit-Kat" over the DM or "WhatsApp", as already advertised by the slogan of a very famous brand 59 .

Recent concepts such as \#tecnofetishism or \#sociophobia have emerged to illustrate non-alignment to the digital relational key. The Spanish sociologist César Rendueles ${ }^{60}$ mentions the need for political change in the digital utopia era, and the Icelandic MP and poet Birgitta Jonsdottir 61 is more emphatic, asserting that the technical change must indeed be accompanied by a change in the democratic structures and dynamics and how decisions are made.

In the category of questions to which no one appears to have an answer, how do we face a change in the structural cycle, when we trust each other less, when we need technological artefacts to accommodate this lack of trust, to even perform a quantum leap towards a new manner of practicing democracy in a direct and networked way? Hardly anything.

6. Social Connectivity: Social Capital in the Community and Impact of Social Networks.

This idea is what Bauman ${ }^{62}$ implies by referring to the idea that we need to protect ourselves from $99 \%$ of the information that reaches us. But how are we

57 | http://ambientcommons.org/

$58 \mathrm{http}: / /$ www.nytimes.com/2013/06/09/fashion/the-i-dos-unplugged-this-
life.html? pagewanted=all\&_r=1\&

59 | http://www.dothegreenthing.com/blog/have_a_wifi_break_have_a_kit_kat

60 | http://www.eldiario.es/cultura/industria-editorial-ocurrir-discografica-Internet 0 174633163.html

61 | http://internacional.elpais.com/internacional/2013/08/23/actualidad/1377252161_022233.html

62 http://www.elconfidencial.com/alma-corazon-vida/2013/05/01/zygmunt-bauman-tenemos-que- 


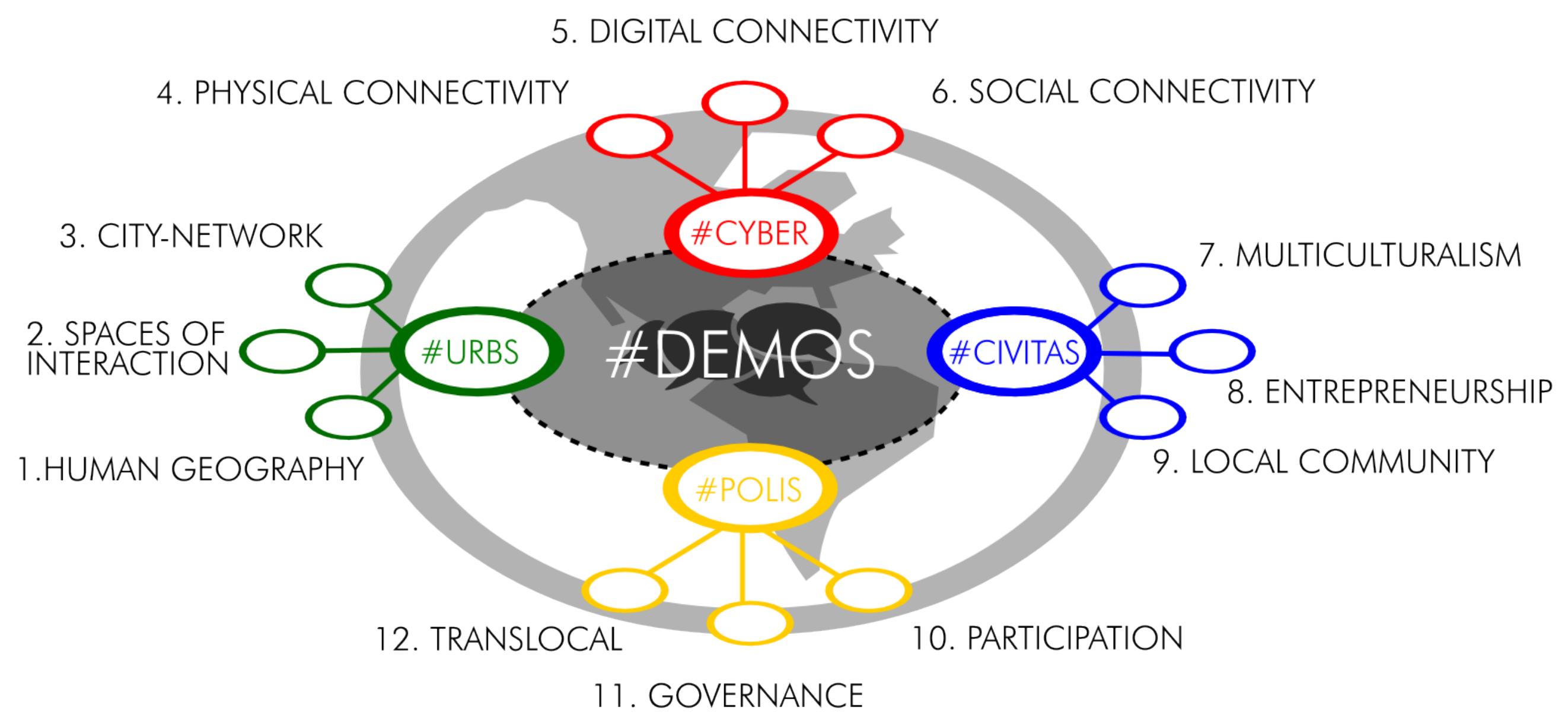


affected by this saturation and information overload in terms of building, maintaining, and transforming Communities? Every time Social Capital is mentioned 63 , there appears to be a need to suggest a society organised without altering or transforming its founding principles, similar to a type of "goodism" that aligns with the institutionalising discourse of Social Innovation. However, the question remains: how do we save, in an effort made almost disproportionate by $\mathrm{Neo}-\mathrm{Communitarianism}{ }^{64}$, the real and necessary value of the Community? Simply, if it is so obvious, why is it falling apart? As Sennet (2013) answers: "because we have forgotten, and therefore need to learn again the value of cooperating and how it is done". Simple.

\section{\#CIVITAS: Socio-cultural System.}

7. Multiculturalism: From cosmopolitanism to translocal diversity.

Keith (2005) already announced that the fever of the cosmopolitanism discourse needed to be put where it belonged: in understanding the urban fact. Beyond the marketing discourse concerning competitive and intelligent cities and territories, the diversity variable is now considered a significant fetish element. Territories must navigate with this variable, but the Territory and the City must be labelled, tagged, mapped, and understood. In that sense, the \#MICRO scale is reproduced in a reticular way in many places, generating what some already call Translocal Geographies ${ }^{65}$. Could we encourage diversity through Translocal Geographies via Social Innovation Projects on the \#MESO scale?

And, how can we slow down or limit the current Gentrification ${ }^{66}$ processes, which would encompass today the concept of Hipsterisation ${ }^{67}$ ?

63 | http://www.variant.org.uk/26texts/LawMooney26.html

64 http://potlatch.typepad.com/weblog/2012/05/new-paper-the-emerging-neo-communitarianism.html

65 | Great work by Brickell and Datta: http://www.localities.kr/sub_pg/img/12.pdf

66 http://www.theatlantic.com/magazine/archive/2010/06/gentrification-and-its-discontents/308092

67 | Interesting study of the Hipster phenomenon and its effect on gentrification processes:

http://www.goodreads.com/book/show/14612369-the-sacred-and-the-profane.
8. Entrepreneurship: Talent, Economic Exchange, Real Economy New Equation, Education, and Enterprise?

The current crisis is bringing an economic cycle change but also a sociopolitical change. What is the New Equation of the Economy and what should it $b^{68}$ ? Furthermore, how are entrepreneurs performing, and why are they in one place rather than somewhere else? 69 Should we continue to discuss models based on the competitiveness variable, or should we move towards a paradigm feeding on Economic Exchange? What role does education have in this context? Regarding the acclaimed value of talent, how is talent hybridised, and how does it coexist with "normal" structures? After all this, can anyone think that the company, as a social institution, is going to remain inalterable?

9. Local Community: Commons and Daily Life?

There is a focus on the local, with authors such as Sharzer (2012) ${ }^{70}$ saying that excessive localism is not the solution and may even become a problem. As we have been arguing, there are some initiatives, such as the Transition Network directed by Rob Hopkins, which have recently been awarded the first EESC Civil Society Prize ${ }^{71}$. What we cannot understand, however, is the relation between the Community and the mechanisms of the Commons at a practical level (Crowdfunding, Goteo or Change.org) and the daily practises of the local community. There are initiatives at a very experimental stage, some which are more advanced, concerning local currencies, food sovereignty, popular supermarkets, local farms, etc. However, the five stakeholders certainly need to reformulate the dynamics and value flows of the Local Community. We are referring here to the common work of (1) public administration, (2) private companies, (3) civil society, (4) academia/science, and (5) entrepreneurs/activists.

68 | Christian Felber le ha puesto nombre, Economía del Bien Común: http://www.attac.tv/en/2012/04/17537

69 | Heather Haverman ha investigado este aspecto

itp://www.irle.berkeley.edu/events/fall11/haveman/haveman oct1 1.pd

70 | http://www.thenorthstar.info/? $p=6926$

71 | http://www.eesc.europa.eu/? i=portal.en.events-and-activities-civil-society-prize-2012 


\section{\#POLIS: Socio-political system.}

10. Participation and Democracy: Activate or Interpret?

We can already hear the slogan "activating civil society", as if someone had (always from the outside and with a more comfortable position than the rest of us) the magical solution to solve citizen apathy regarding the political system. It sometimes appears as if we want to supply political, institutional, and business responsibilities with delegation processes towards civil society and the opposite, by which civil society is the recipient of collective decisions made in assembly formats. Perhaps, as Daniel Innerarity argued, we need a society of interpreters ${ }^{72}$. There are simplistic discourses suggesting a very fast solution without internalising the change and looking for solutions from the inside towards the outside. We must still interpret what happens and why it happens. The \#MESO scale certainly has in its big black box solutions to the problems we should be solving.

1. Governance, Regulation, and Compact: Stakeholders?

Castells already said that the left had died, and Innerarity also reasons against ideological nostalgia and against the need for reformulating political concepts such as left vs. right and sovereignty. What type of compact is possible? What regulations are necessary to achieve democratic governance? Innerarity reminds us that the solutions brought by digital democracy have demonstrated that it is necessary to disentangle the illusion: "The enthusiasm surrounding technology has simplified the vision of its political effects"73.

It is obvious that we need a political renovation. The importance of being controlled, the need for not being controlled, transparency vs. publicity, staged proximity, the devastating effects of political immediacy and digital

sanctimoniousness, the value of mediations, and, finally, which power for the people, are some of the issues that may help us in this endeavour (Innerarity, $2013)^{74}$

72 | http://elpais.com/diario/2010/11/16/opinion/1289862004 850215.html

73 | http://elpais.com/elpais/2012/02/28/opinion/1330446416_732470.html

74 | http://www.globernance.org/daniel-innerarity-el-dominio-publico-un-decalogo-para-la-renovacionde-la-politica-3/2lang $=$ es
12. Global and Local: Translocal?

Paraphrasing Beck (1992), "We are looking for partial solutions to global problems". Like Harvey et al., Beck agrees with the idea that this capitalism is not providing answers to the crisis $^{75}$. The excessive insistence on globalisation but, at the same time, the great illusion and insistence on localism incite us to believe that we need to conjugate another vision on the \#MACRO scale, another territoriality. Between Global Villages ${ }^{76}$ and Translocal Geographies, we should be able to articulate a new territoriality that would not become lost in close-ups but would not expect external solutions either.

How to \#BeHereWhileBeingThere? (or what, in Basque, the prolific writer Joseba Sarrionandia called, \#HanlzanikHonaNaiz or \#BeingTherelAmHere.

We will return to the initial question, asking whether the world is flat or hilly, a debate that Florida vs. Friedman impersonated in 2005. The power of networks ${ }^{77}$ may help us imagine what this new translocal territoriality could be.

\section{\#DEMOS}

It is obvious that, in line with Innerarity, Subirats, Castells, and Bauman, another society, other politics, and ultimately, another democracy, or \#DEMOS, will emerge because of everything that we mentioned before. Could it be towards a \#DEMOS of commons ${ }^{78}$ ?

75 | http://www.publico.es/410294/este-capitalismo-no-da-respuestas-a-la-crisis

76 | http://p2pfoundation.net/Global_Villages

77 | David de Ugarte. El Poder de las Redes. (2007)

$78 \mid$

http://www.academia edu/1574270/Otra sociedad__Otra politica. Del No nos representan a la dem ocracia de lo comun 


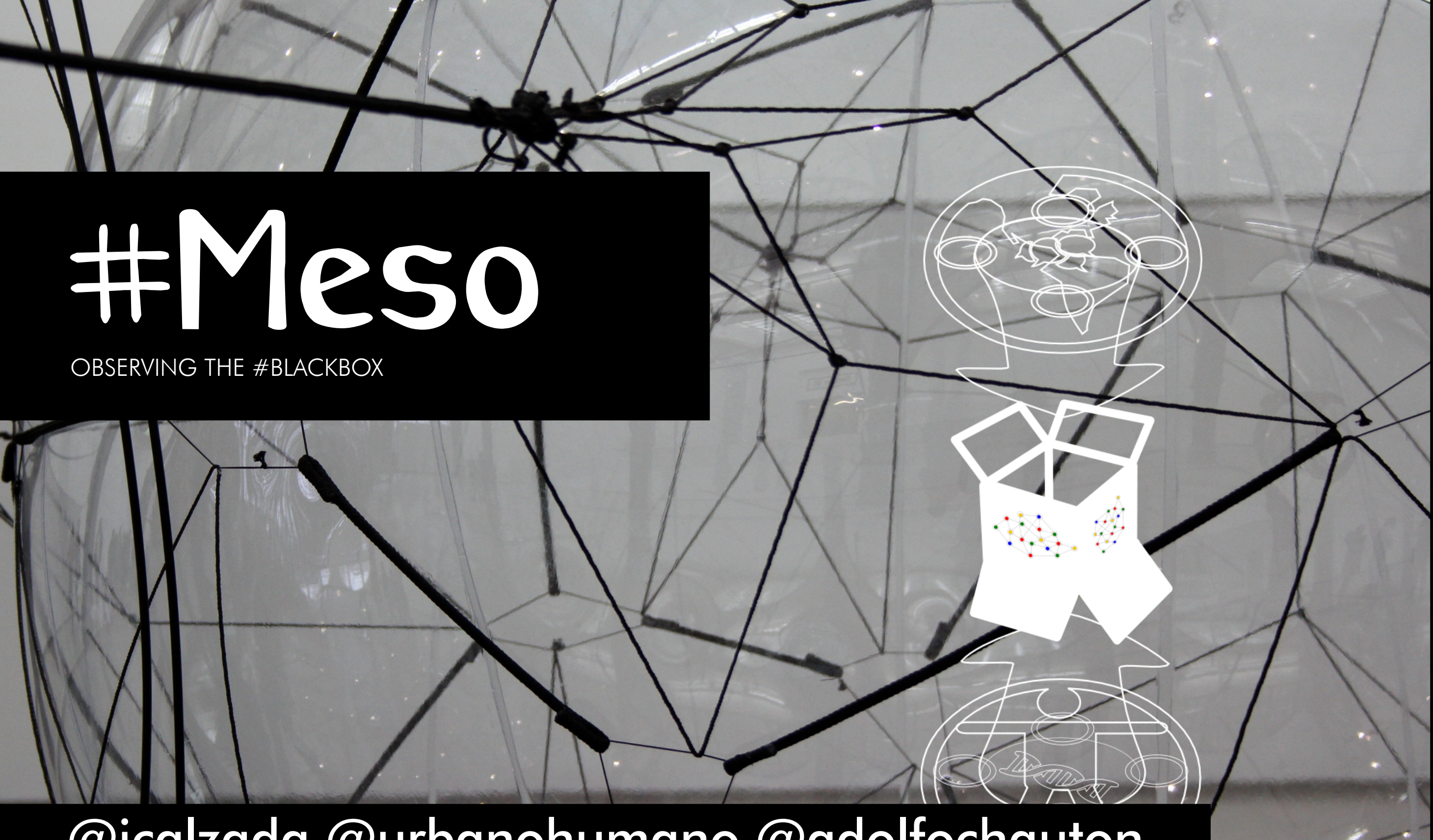

@icalzada @urbanohumano @adolfochauton
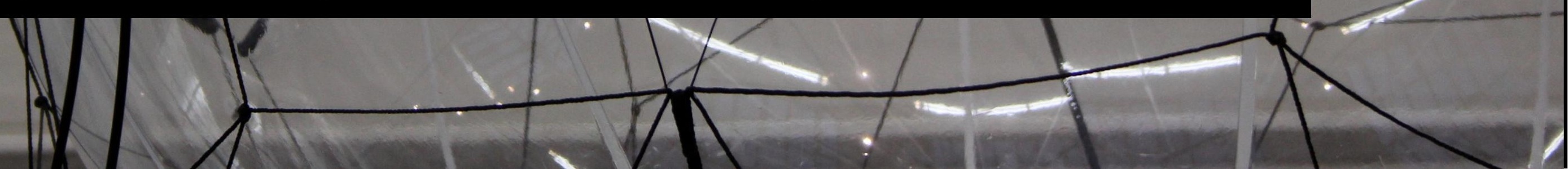
To respond to the black box investigation, it is necessary to describe the affinity of the five systems of the \#Macro and \#Micro scales. Thus, we have based our analysis on the organic vision determined by the tree metaphor. Within this very metaphor, the connection of the \#Macro system with the \#Micro system is determined, yielding the following relationship among systems:

$$
\begin{aligned}
& \# \text { EARTH }=\text { \#URBS }+\# \text { HAND }=\text { \#MAKING } \\
& \# \text { AIR }=\# \text { CYBER }+\# \text { MIND }=\# \text { THINKING } \\
& \# \text { FIRE }=\# \text { CIVITAS }+\# \text { SOUL }=\# \text { ENVISIONING } \\
& \# \text { WATER }=\# \text { POLIS }+\# \text { HEART }=\text { \#VALIDATING }
\end{aligned}
$$

Based on these relations, two Input and Output tools have been developed in the Operational Application section.

Twelve elements are used within these tools, which are supposed to be answered by the participants individually and collectively. These elements are:

\section{\#MAKING: \#URBS+\#HAND}

\section{\#MESO APPROACH}

\section{OBSERVING THE \#BLACKBOX}

@icalzada
@urbanohumano
@adolfochauton

Agents: The Human Geography \#URBS and Human Needs \#HAND factors provide insight into the subjects. These two factors represent the most objective determine the evolution of the Territory as they configure their relations. The scores with refer to the capacity of resilience that the agents present.

Benefit: The Spaces of Interaction \#URBS and Triple Bottom Line \#HAND factors configure this element. Benefit refers to the scope that the exchange and production of value have. The scores will be given depending on how parts. As we explained in the introduction, the decisions made by the actors 
significant the Benefit is when using and rationalising the Territory's interactions and resources.

Entropy: The City Network \#URBS and Sustainability \#Hand factors are the basis of this element. Entropy refers to the cost-benefit analysis that the Social Innovation process requires in the Territory that is being analysed.

\section{\#THINKING $=$ \#CYBER +\#MIND}

Toolkit: The Physical Connectivity \#CYBER and LivingLab \#MIND factors represent the basis through which the Social Innovation process becomes tangible. The scores will be given by attributing a value to the real possibilities of the Territory being analysed with regard to facilitating artefacts.

Media: The Digital Connectivity \#CYBER and Free Culture \#MIND determine this element. The scores will be determined by the level of maturity of the Social Innovation process in the Territory in terms of how it addresses digitalisation.

Network: The Social Connectivity \#CYBER and Collective Intelligence \#MIND factors refer to the development of social networks into social capital and, from there, into emerging expressions of collective know-how. In other words, the point is that the scores would be given according to the ability of a Social Innovation process in a Territory to display Collective Intelligence on the \#Micro scale, and Social Connectivity on the \#Macro one. This network should be rooted and located in the Territory as a sine qua non condition to be regarded as highly relevant in its systemic dimension.

\section{\#ENVISIONING = \#CIVITAS+\#SOUL}

Mission: It is consubstantial to the objective of Social Innovation insofar as we must incorporate an Entrepreneurship \#CIVITAS and an Optimal Experience \#SOUL. We must not consider that this element is present in all territories. In many Social Innovation processes occurring in Global-South countries, the \#AIR \#CLOUD

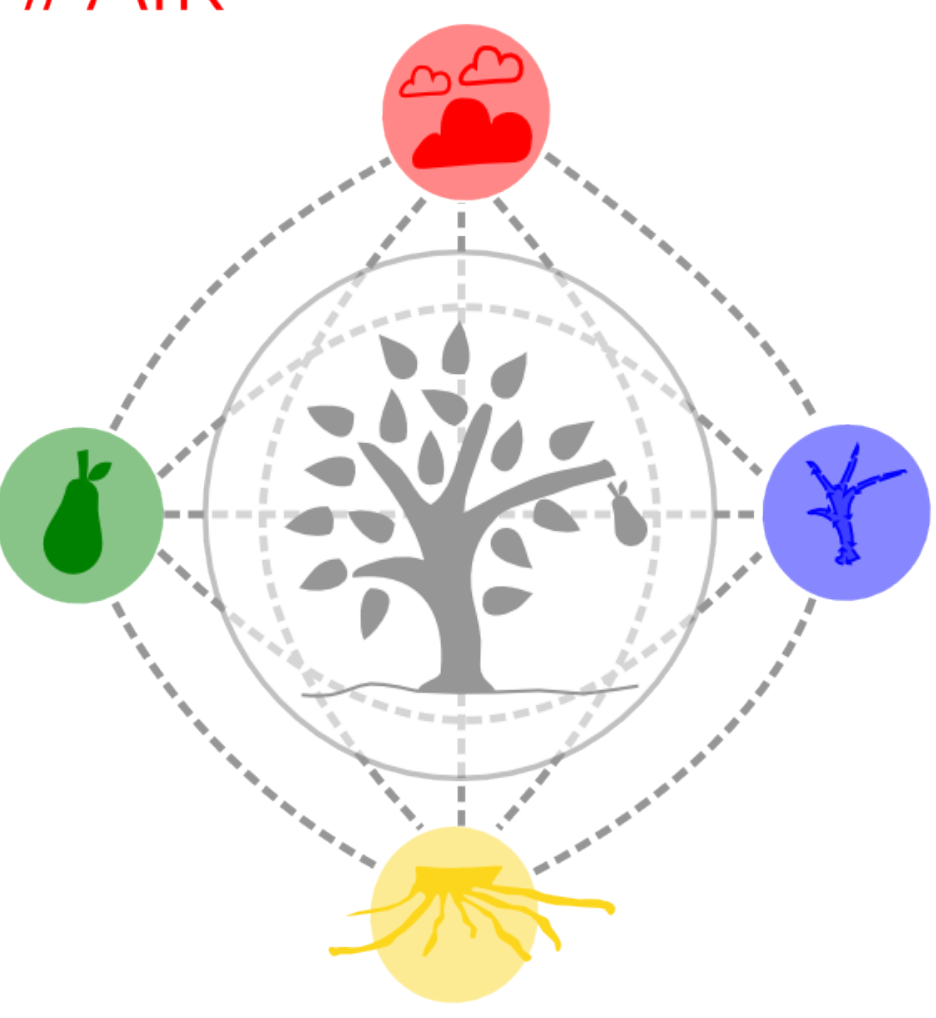




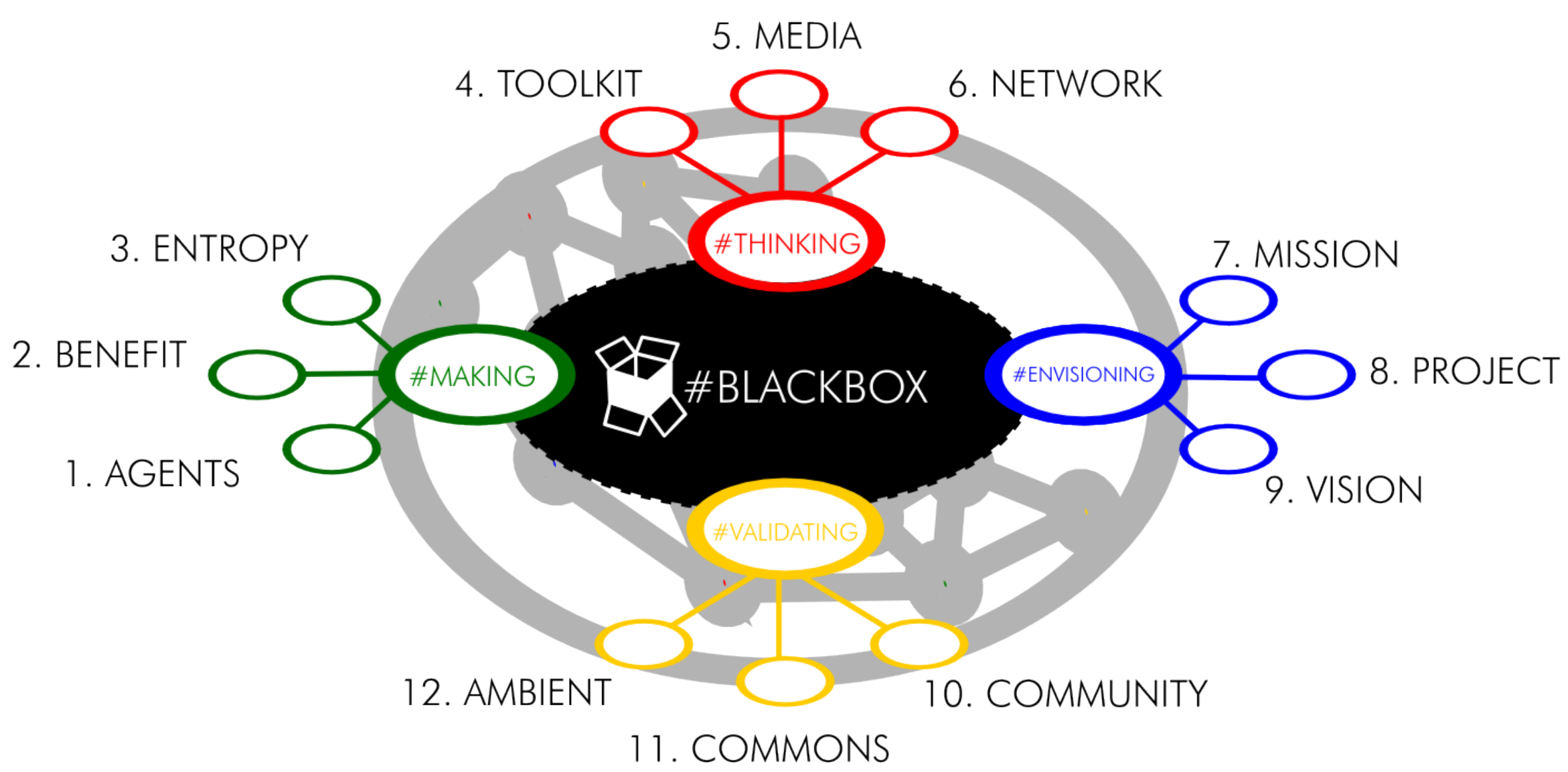


initiative and the possibilities of articulating Social Transformation are not significant. The scores will be determined by the possibility of displaying this ability on the \#Macro or \#Micro scale.

Project: The Local Community \#CIVITAS and Innate Genius \#SOUL factors refer to the very mechanisms that the Social Innovation process presents to develop. The scores will be related to the degree of viability that the project presents.

Vision: The Multiculturalism \#CIVITAS and Interculturalism \#ALMA factors define this element, considering that they must be supported by a vision of interdependence with diversity, or, in other words, the social innovation processes that are being analysed should effectively consider the incorporation of a vision that would encompass in the long term the changes in the composition of the global world. The ability to give this element in the Social Innovation processes that are being analysed will determine the participant's scoring.

\section{\#VALIDATING = \#POLIS + \#HEART}

Community: The Participation \#POLIS and Implication \#HEART factors generate the Community element. The scores are determined by the degree to which there is a positive and proactive activity within the Community.

Commons: The Governance \#POLIS and Consensus \#CORAZON factors determine this element. The scores will be determined by the ability of the Social Innovation process to achieve agreement and consensus.

Ambient: The Translocal \#POLIS and Genius Loci \#HEART factors are the components of this element. Concretely, Ambient is the part of the Territory where the Social Innovation process is sprouting. The scores will depend on the quality of the context in which the Social Innovation process is undertaken.

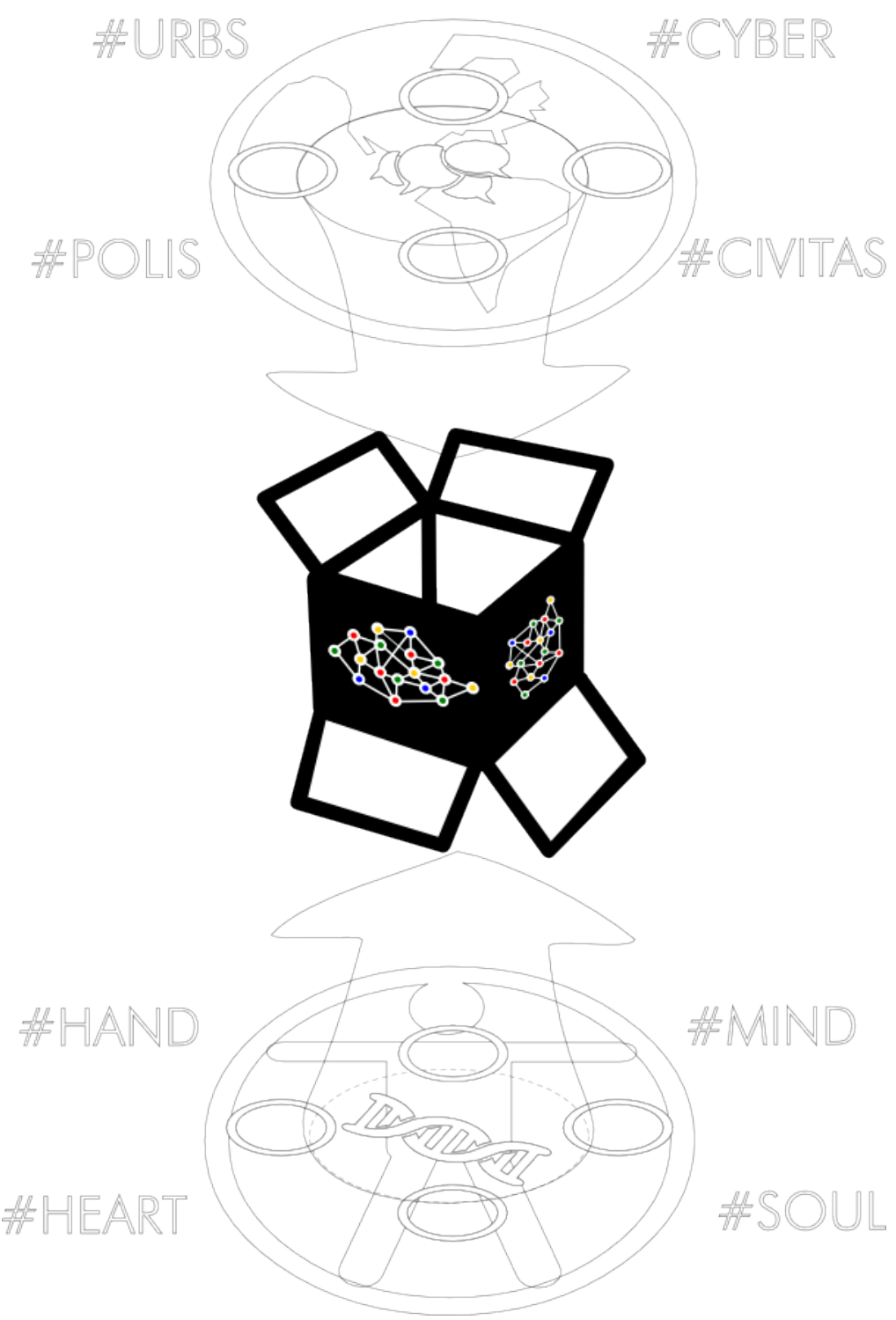




\section{\#Micro}

[\#HAND $\mid$ \#MIND $\mid$ \#SOUL $\mid$ \#HEART] = \#OPEN_NDA

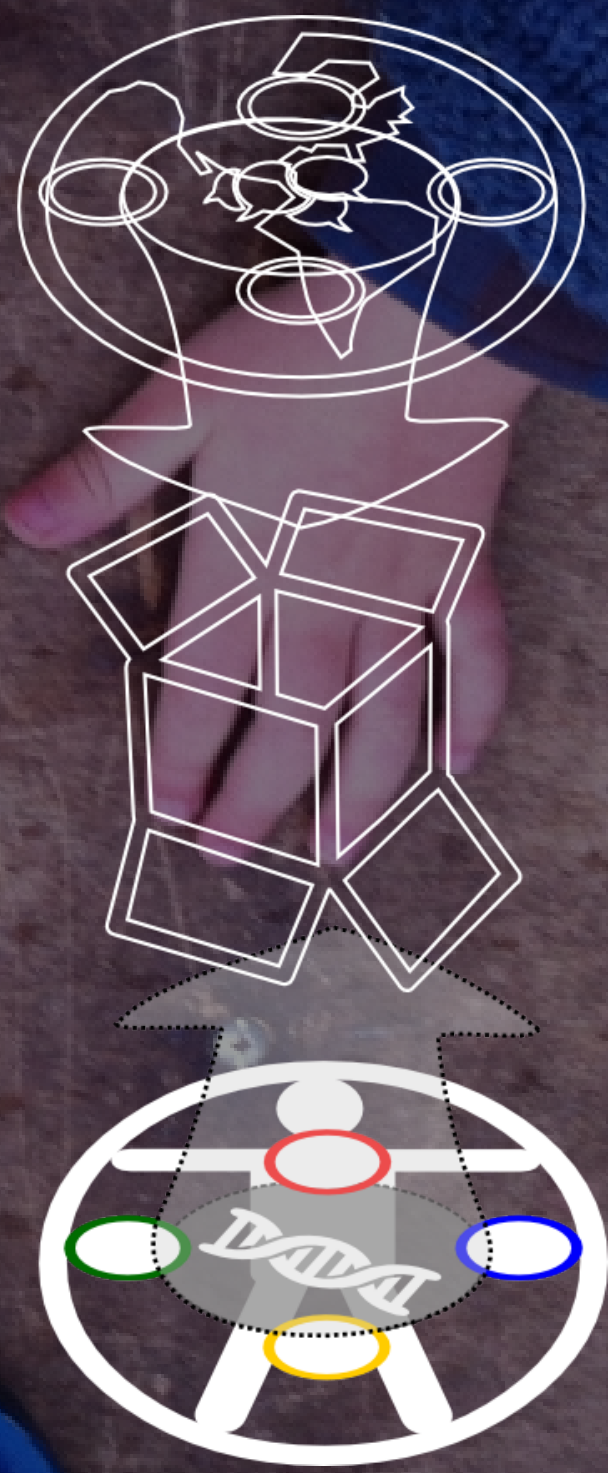

@adolfochauton 


\title{
\#MICRO APPROACH
}

\author{
[\#HAND $\mid$ \#MIND $\mid$ \#SOUL $\mid$ \#HEART] $=$ \#OPEN_NDA
}

\section{@adolfochauton}

"You are not an isolated entity but a unique and irreplaceable part of the cosmos. Don't forget it. You are an essential piece of the jigsaw of humanity."

This \#MICRO scale, from the people, that is presented here is the result of a process of creative suspension ${ }^{79}$ caused by a biological parenthesis in @adolfochauton's work path, which allowed the generation of a critical reflection upon his professional development and especially on the human factor and its significance in achieving the positive transformation of any environment.

This scale unfolded with the view of making it useful to our daily environments, to create a hybridisation of small activities, actions, and projects that were halfway between the tradition of convenient trading, mutual support networks, café gatherings, and/or self-managed cooperatives but fundamentally reinterpreted from current and future keys and opportunities.

79 | Creative suspension is the main contribution made by F. David Peat in his highly recommended book, Gentle Action. This concept consists of what he defines as "the voluntary act, on the part of an individual or an organization, to suspend, even if it lasts for one second, their usual automatic reaction, their reflex, of pressing themselves to help or to " arrange". 


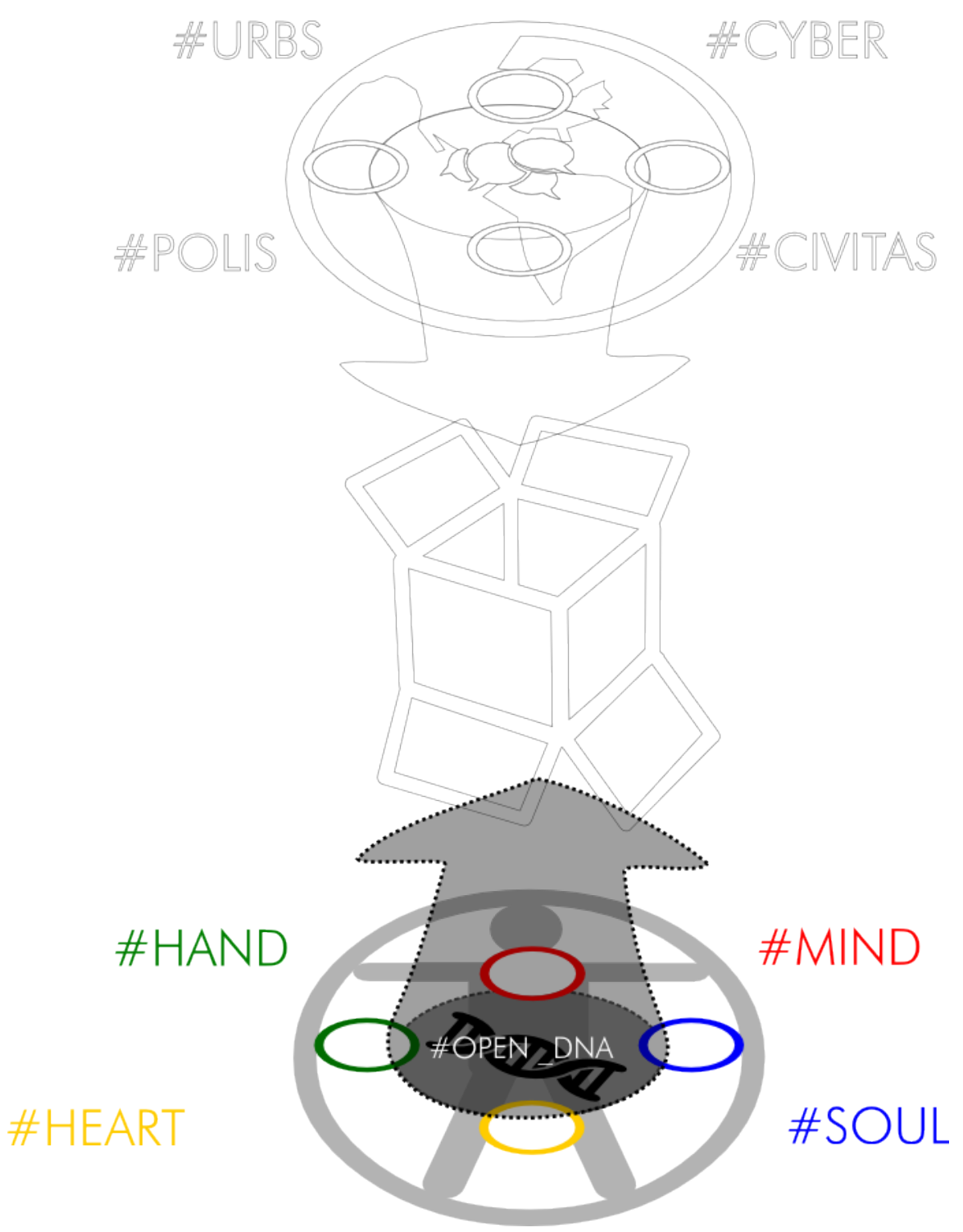

\#HAND: Physical and Material System.

1. Human Needs: Scarcity vs. Opportunity.

"Hunger stimulates cleverness" according to a Spanish saying. "No one is embittered by a sweet" argues another one.

At which point can human needs stop being exclusively needs and become a complex duality between need and opportunity? This question is a key issue. Facing life from need is not only a way to stimulate cleverness to find immediate solutions (I need to eat) to concrete problems (I am hungry).

As Robinson (2009) argues, the education that most of us have received, and which remains in force, despises and disregards creativity, emphasising this posture, which ends up perpetuating need and, by the same token, scarcity, causing them to become chronic.

Attending, or contributing to attend, the survival instinct (food, shelter, affect, rest) is, more than necessary; this instinct is vital. However, it is as vital to maintain the survival-transcendence tension ${ }^{80}$. Can we break the cycle of chronic scarcity and find space and time to see life from a broader perspective? This process is not simple. Accomplishing this change entails finding the nuances that may enable us to tune into our creative/creator power with other ways to conceive nature and other productive methods to, subsequently, satisfy our needs (Shiva, 2008).

\section{The triple benefit: Dreaming in legitimate defence}

Innovation is applied imagination. In 2005, Extremadura gambled by leading what it called the Society of Imagination in an attempt to jump directly into the economy of knowledge. "Being efficient is not enough anymore. What matters is to be different, and if possible, unique" 81 . Hasn't there been anything similar already since Ford's dream came true that every worker should have his own

80 | Carl Gustav Jung introduces the idea of a tension between the survival instinct and transcendence impulse: http://es.wikipedia.org/wiki/Carl_Gustav_Jung

81 | Juan Carlos Rodriguez Ibarra.

http://elpais.com/diario/2009/04/25/opinion/1240610404_850215.htm 
vehicle or Disney's dream of homogenising the global child imaginary? Is there any difference between the American dream and the Extremaduran Society of Imagination? There should be one: the same that exists between Bill Gates and Tim Berners-Lee, that is to say between a young American who became rich almost by accident by patenting a "global" operational system and a mature British man who prioritised transforming the world 82 by his exclusively individual development, opening the World Wide Web code. It is the same difference that exists between linear technological innovation and cyclical Social Innovation or between the teenage garage innovation and the conscious vegetable patch innovation ${ }^{83}$.

In this context, it is necessary to take a position; dreaming is not a romantic option anymore: now it is a question of legitimate defence because if one does not articulate their own utopia (individual and collective), they expose themselves to live the one that someone has already dreamt, through mortgages, patents, restrictions, etc.

The current global crisis requires a lot of applied imagination, it requires a Society of Imagination working with full yields and that is able to see and do things differently ${ }^{84}$, it mainly must apply all possible imagination to the common welfare, with a triple benefit ${ }^{85}$, that we decided to call Social Innovation. Otherwise, applied imagination simply means accelerating the deterioration and accentuating the deep global crisis of everyone against everyone.

\section{Sustainability: Between Deficit and Saturation}

The first assault sets the concept of sustainability against that of sustainable development. Is not sustainable development economic growth 3.0?

82 | In an interview in the "Pienso, luego existo" program of RTVE, Manuel Castells declared: "I know Tim Berners-Lee well, and I once asked him: If you had put a copyright on www that we all have to use all the time, you would be bigger than Bill Gates. Yes, but l wouldnt have changed the world."
http://www. rtve.es/television/20130616/sociologo-manuel-castells/686369.shtml

83 | Documental "La voz del viento". http://vimeo.com/59138479. Highly recommended.

84 "Another way to see and do things" was the motto of the Gabinete de Iniciativa Joven, which no onger exists, an organism created by the Regional Goverment of Extremadura to impulse the Society of

85 | http://en.m.wikipedia.org/wiki/Triple_botton_line
Sustainability imposes itself. The second assault opposes sustainability, and sustainability, that is to say, the biased approach from the global-North ${ }^{86}$, prioritises solidarity with future generations over solidarity among existing generations. The other sustainability also imposes itself, the one called viability, which is defined as the full human development within the environmental limits of the planet ${ }^{87}$.

This definition helps us to correctly define the challenge: in reality, sustainability is a dynamic stage that is reached when a territory is able to guarantee the full development of its human geography (overcoming scarcity) without surpassing its physical limits, that is, its regeneration ability (limiting saturation). Is sustainability compatible with the current models of land occupation? Can cities, where more than $50 \%$ of the world's population already lives, face this challenge on their own?

Manfred Linz (2007) offered a key contribution: "Sustainability can be achieved by three different routes: efficiency, coherence and sufficiency 88 . None of these routes, without the others, can take us to the objective", or as the poet would say89: "Maybe man's future will have to be crafted, in cities where the emergencies do not defeat us, in lands where the trees help us breathe, in times and places where we can die in peace in the end, knowing that humanity has earned the right to survive us."

86 | http://en.m.wikipedia.org/wiki/Our_Common Future

87 | http://www.footprintnetwork.org

88 Efficiency is aiming towards improved use of matter and energy, that is to say, towards improved productivity of natural resources. Sufficiency is about achieving improved consumption of resources by nature, which would use ecosystems without destroying them.

$89 \mid$ Mario Benedetti, Subdesarrollo y letras de osadía. 


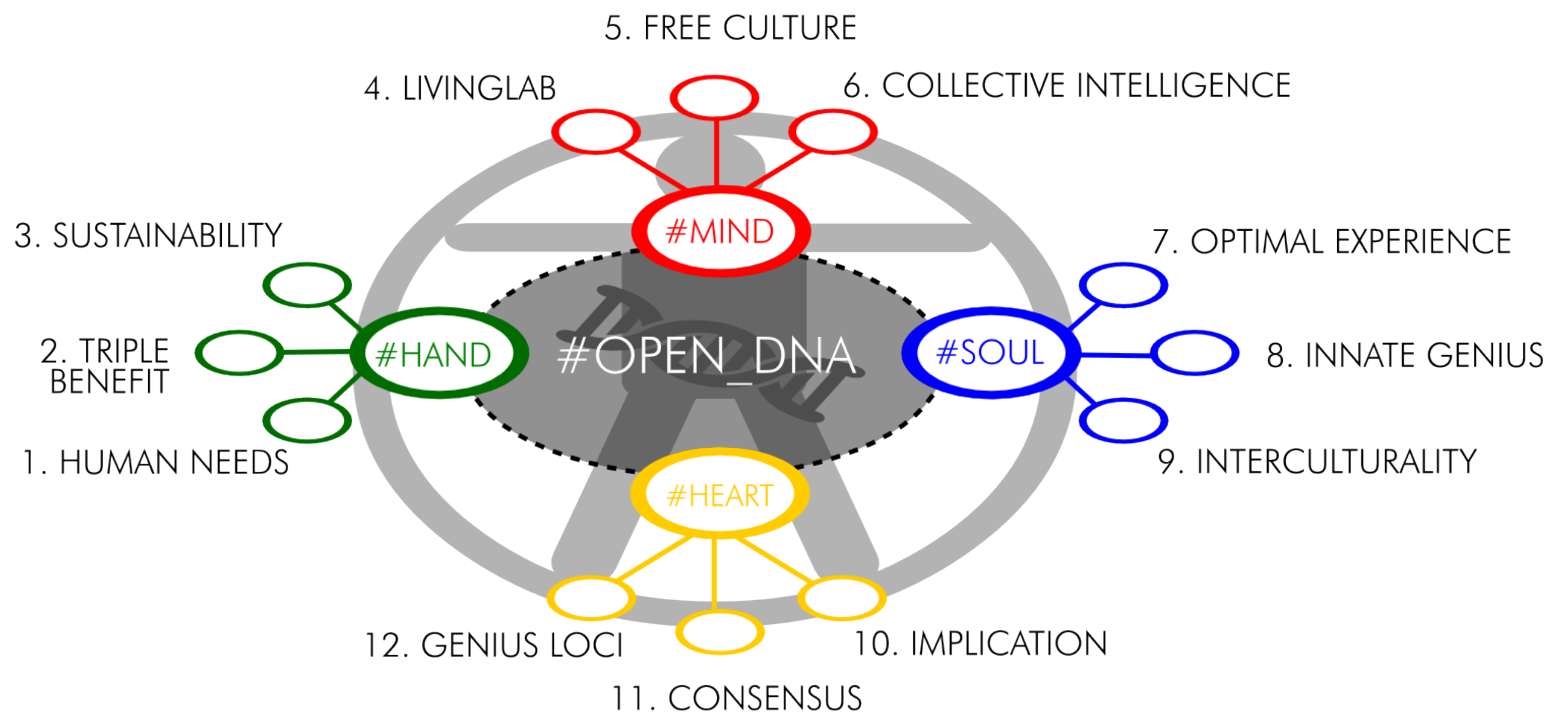




\section{\#MIND: Cognitive, Remote, and Virtual/Digital}

4. LivingLab, re.qualifying by doing.

"Most people have the spirit, the abilities, and the knowledge that are required to participate in a designing process" 90 . There are increasingly more initiatives that appear to attempt to provide us with the means to do things in a new way, where open learning (know how to know) converges with self-oriented learning (know how to be) through actions (know how to do). LivingLabs are one of these initiatives.

The interesting point comes when the goal is not to produce great inventions or applications that may become a business buzz. In most cases, these open design processes can help us bring subtle changes to our ways of doing things and interacting and of seeing the world on a daily basis.

However, over the past few years, we have observed the democratisation of digital production means (capture, edition, and distribution), giving anyone the opportunity to build their media autonomy, which was not conceivable until now, even opening interesting processes of internal reflection and collective new training ${ }^{91}$.

However, the key is the behaviour that we adopt, whether or not we assume the fact that Social Innovation is living in an on-going process of new abilities, which forces us to constantly recombine abilities and new training.

5. Free culture vs. patented cultures.

You cannot by yourself, you can with friends ${ }^{92}$. We are experiencing the emergence of a hyper-connected society (Reig, 2012). The Internet and its

90 | http://opendesignnow.org/

91 I In 2010, Ubiqa developed a project for Anesvad in Peru (and in Bangladesh) of participative audiovisual creation to produce a collaborative documentary to give voice and implication to the vulnerable populations from the South: http:// www.ubiqa.com/seguimos-creyendo-que-es-posible\%E2\%80\%A6-y-
vamos-a-contarlo/. "Today, the poor cannot be made invisible as was the case 50 years ago". Ollanta vamos-a-contarlo/. "Today, the poor cannot be made invisible as was the case 50 years ago". Ollant
Humala, President of Peru http://internacional elpais.

92 | http://www.colaborabora.org/2012/12/26/guia-incompleta-para-colaborar/ evolution towards web 2.0 have allowed the emergence of the prosumer, hacker, open, hybrid, crowd, etc. philosophy, together with the concepts of free culture that we could synthesise as Download! Change! Redistribute!

We are witnessing an awakening of the collective conscience; the "internet environment" is devirtualising the collective subconscious and has managed to make our shared brain tangible. But how does and how can the emergence of this free culture affect the institutions and the ideological and religious pillars that are so used to control the supra-human spheres of our lives?

The story began with the emergence of communities distributing the development of free software, which showed us, whereas we had lost hope, not only that massive collaborative creation is possible but also that it can be performed openly and requires P2P communities to have a real development.

The change was absolutely drastic and still has some potential to be discovered, but could it be generating disproportionate optimism? Do we know how we can learn to control its strength? Is it really the solution to all our problems? Does it radically replace everything we know, or does its strength rather stem from its ability to open alternatives?

6. Collective Intelligence, periphery is a way of being.

Rifkin introduced us to the Age of Access ${ }^{93}$. This access affected our means of relating to technology and to other people. We have experienced the effect of Social Networks and their potential effect in changing our behaviours. This behaviour incites us to open ourselves and have access to leave the periphery, to what makes us part of something, to belong to something, to cultivate Social Capital. It is and could be a maximisation of social opportunities and of the artefacts of ubiquitous technology, increased and distributed, the cause through which the processes of collective intelligence can occur, not any other way, considering that there is a high probability that these processes could emerge from the serendipity of Social Innovation processes. $93 \mid$ The Age of Access: The New Culture of Hypercapitalism, Where all of life is a Paid-For Experience. J.P.
Tarcher/Putman, 2000. 


\section{\#SOUL: Intangible and Transcendental System.}

7. Optimal experience, each person is an artwork.

Silently, a deep mutation of values is occurring at the collective level but with an individual expressive nature (Pigem, 2011).

Csikszentmihalyi (1996) says that when we lose the notion of time by doing something that makes us feel special and connected, we are in a flowing state, in an optimal experience where our personality grows, making us more complete and more complex.

Everybody possesses some explicit or diffuse creative potential and abilities or talent that they can potentially develop (Ken Robinson, 2009) ${ }^{94}$, and this development is a potential benefit-opportunity for the person him/herself, for his/her community, and for his/her environment and/or territory.

Connecting ourselves to that talent is the basis of our - intrinsic - motivation, and when that talent aligns with the vital realities of other people (extrinsic motivation), we enter a flowing state that extends our conscious and makes us more complex and complete (transcendental motivation).

Saturated with the toxic, the false, the noise, the smell of plastic, the made-inChina and the papier mâché, we need to return to the truth and "realistically" develop our particular personal utopia, taking care of our sensitivity and of the impulse given by our intuition to transcend and be part of something greater than "consuming to death"95.

\section{Innate genius}

"All knowledge comes from doubting, from ingenuity" (Morin 2002).

"Apparently, in some way, each person needs to discover what being original

94 We could define diffuse talent as talent that is not necessarily tangible nor bankable and that, in many cases, the person him/herself is not fully aware of having.

95 | translation from "Consume hasta morir". Is the name of campaign started by the Ecologist in Action association. www.consumehastamorir.com and creative means... originality and creativity can only be developed if they have the essential force that impulses the real first step" (Bohm, 1998).

The process of creative construction gathers three qualities that interact and nourish each other in a fundamentally dynamic process: be ingenuous, be ingenious, and the search for our genuine self. In fact, it cannot be coincidental that the three qualities have the same etymological basis (gen, in), which refers us to the concept of innate genius that they define together.

Discovering our genuine reality requires a great creative effort and trust in the thing in which a person really is able, if he/she persists, to achieve the goals he/she sets. These are the cements of the creative processes that we must face because "we are the artists of our lives, whether we know it or not, we want it or not, and we like it or not" (Bauman 2009).

9. Interculturalism

Difference must be an asset. Diversity [diversity = different people] could look like a behaviour before the community. To which point do we assume difference in our coexistence? Identity separates us and brings us together. We keep learning how to mix identities, how to start with what we are, and end up being everyone else to some extent [diversion $=$ different experiences]. Getting out of identity borders, moving to others' normative parameters, values and beliefs, is an act that constitutes the main intercultural practice. When does this process end? Or have we reached this process to never end it and know that we are defending our particular identity area? Is my difference so different that it does not look like the differences that other people have surrounding them within the community where I live? Maybe it is not a question of a selecting but rather of appropriating my neighbours' existential narratives [divergence $=$ different points of view]. The more diverse they are, the more different I will be and the more adapted I will be to a continuous migratory evolution of nomadic citizens in places we build together. Otherwise they would be places, they would be something else: spaces that you enter and never exit or exit always remaining the same. 


\section{\#HEART: Emotional and Closeness System.}

10. Implication walk neyt to me and this way we't l be equal96

Minsky (1988) declares that there is nothing in our brains that is similar to a general manager, a prevailing "I" that controls what we think, say, or do but, rather, that the brain is a troop of individual "actors", each one of them having the ability to function independently. One of the most recurring axioms in business environments is the maxim: "The most important factor to succeed in any professional career is to surround ourselves with the best"97. But what happens when our company, our task, is our own environment, our city, or the territory where we live? To a certain extent, liability should always be joint. Were the best born? Can they be found? Listed? Made? Who are they, and who or what determines them? Can we only achieve Social Innovation with the best?

Success may not be an individual achievement but rather an environmental factor, an aroma, a sensation.

In any place, environment, context, or territory, there are hidden talents (diffuse, dormant, repressed) that may be extraordinarily significant to the global health of the group. In other words, the best are those who are, the people who are already part of it. There is no need to resort to injecting or attracting creativity (with or without class) or external innovation, surrounding oneself with the best, or listing "the good ones". The challenge is to activate and exploit the talents, vocations, sensitivities, and intuitions of those we already are, to move from being part to taking part, and ultimately, have a part, radically in getting involved. "And then we'll be equal".

96 adapting by Escuchando a Tagore, a song of La Familia Iskariote http://www.ouvirmusica.com.br/la

97 | http://www.iese.edu/Aplicaciones/News/view.asp? $i d=3522$
11. Consensus, bevond the demecracy of parties

Solving a deliberation or a collective conflict through a voting process results in generating two opposed positions ${ }^{98}$ : the people who are in favour and the people who are against. If, in addition, we adopt voting as a usual practice, the differences end up being irreconcilable. The democracies of parties is a democracy of minima, which gets us used to constantly living in a climate of hostility, confronting each other.

Robinson and Acemoglu 99 argue, in their theory of extracting classes, that real inclusive institutions, those that are observed in open societies, are the ones that contribute the most to fertilising the ground to achieve a nation's prosperity. Molinas has adapted this theory to the Spanish case ${ }^{100}$ and argues that the Spanish political class has developed, over the past decades, a particular interest, which is supported by a system of capturing rents that is placed at a higher level than the nation's interest. The 15M declaration was thus better aimed than it seemed: "it does not represent us" and has never had any intention to.

The institutions would always be confronting each other and deactivated. Have we transferred the material culture of using and throwing the sphere of relations and coexistence? Bad omen. It may be the great challenge faced by the Commons: Can we create processes that would positively take care of the conflict among people, the community, and the process itself?

12. Genius Loci: "each one gives what they receive, then receives what the give 101

Joel Kotkin (2006) argues that in the global history of cities, three factors have

98 | Lo contrario a un proceso de votación podria ser un proceso de toma de decisiones por consenso, es interesante el enfoque y metodología del http://www.iifac.org/

99

http://economia.elpais.com/economia/2012/03/23/actualidad/1332522818 318468.html http://elpais. com/elpais/2013/05/30/eps/1369930831 246722.html

100 | http://politica.elpais.com/politica/2012/09/08/actualidad/1347129185_745267.html) 101 Adapted by Jorge Drexler's "Todo se transforma" http://www.vagalume.com.br/jorge-drexler/todo-se- 
imposed themselves as being decisive in the flourishing of urban culture: the sacred dimension of the place, the ability to provide security and a power project, and, finally, the invigorating role of trade.

We abandon places to live in transit throughout the non-places ${ }^{102}$.

The axiom "there is no innovation without tradition, nor tradition without innovation" immediately positions us at the edge of the precipice. What type of innovation do we produce then in these so-called non-places?

The non-places feed the self-made entrepreneur myth, the one of the Crack signed up to win the League, the innovator as a lonely leader, the parachutist who, no matters where he comes from, can make us survive, in times of hardship or scarcity.

However, places provide us with another strategy, that of symbiosis (our environment affects everything we do, everything we do affects our environment), which invites us to hold ourselves on what pervades (the sacred, \#MACRO \#CIVITAS?), to generate dynamism (market, \#MACRO \#URBS?), and to facilitate conviviality (security + coexistence + hope, \#MACRO \#POLIS + \#MACRO \#CYBER?) to feel, in short, important (\#MACRO \#DEMOS?). Because place matters.

Place matters because it is the framework of common life, "the support to community: necessary structures to reduce - Manage? - uncertainty and incentivise philanthropy" (Hernández Renner, 2012).

Place matters because it shelters and shares with us its own essence or spirit that has been fashioned with the way of seeing and being in the world of the people who have inhabited it across history and who, in exchange, received the opportunity to find their relevant place within the Totality (Norberg-Schulz, 1980).

102 | http://es.wikipedia.org/wiki/Marc Aug\%C3\%A9
Place matters because it is the anchoring point from which we can understand the world, and "our understanding of the universe affects all the aspects of our interior life, from our highest spiritual convictions to the most trivial details of our daily experience. Conversely, the deep dispositions and the character of our interior life penetrate and completely configure our understanding of the entire cosmos" (Tarnas, 2006).

To summarise, place matters for bringing meaning and transcendence to what we do, giving it a quality of a vital project and making us grow both individually, as a person, and collectively by improving our contexts, neighbourhoods, communities, villages, and/or cities.

\section{\#OPEN DNA}

\section{\#OPEN_DNA}

The concept of open DNA 103 takes us to the only (open) code we understand, which is the basis on which any Social Innovation project must be created. Open DNA is open in two ways: "open" as opposed to "closed" and "open" as "in progress" and cannot be any other way. 


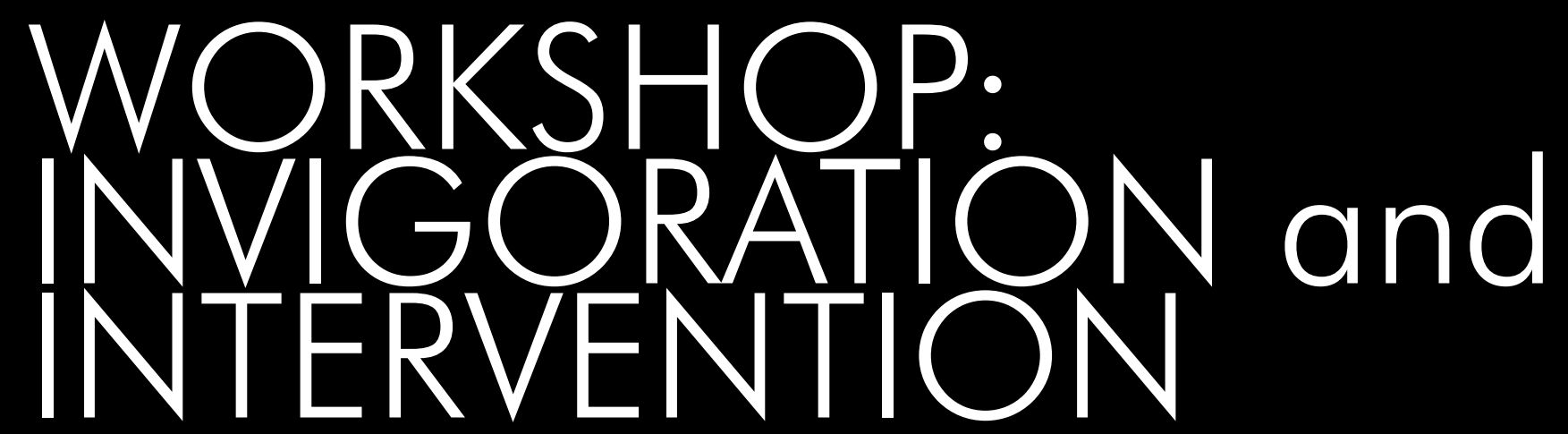

@adolfochauton 


\section{OPERATIONAL APPLICATION}

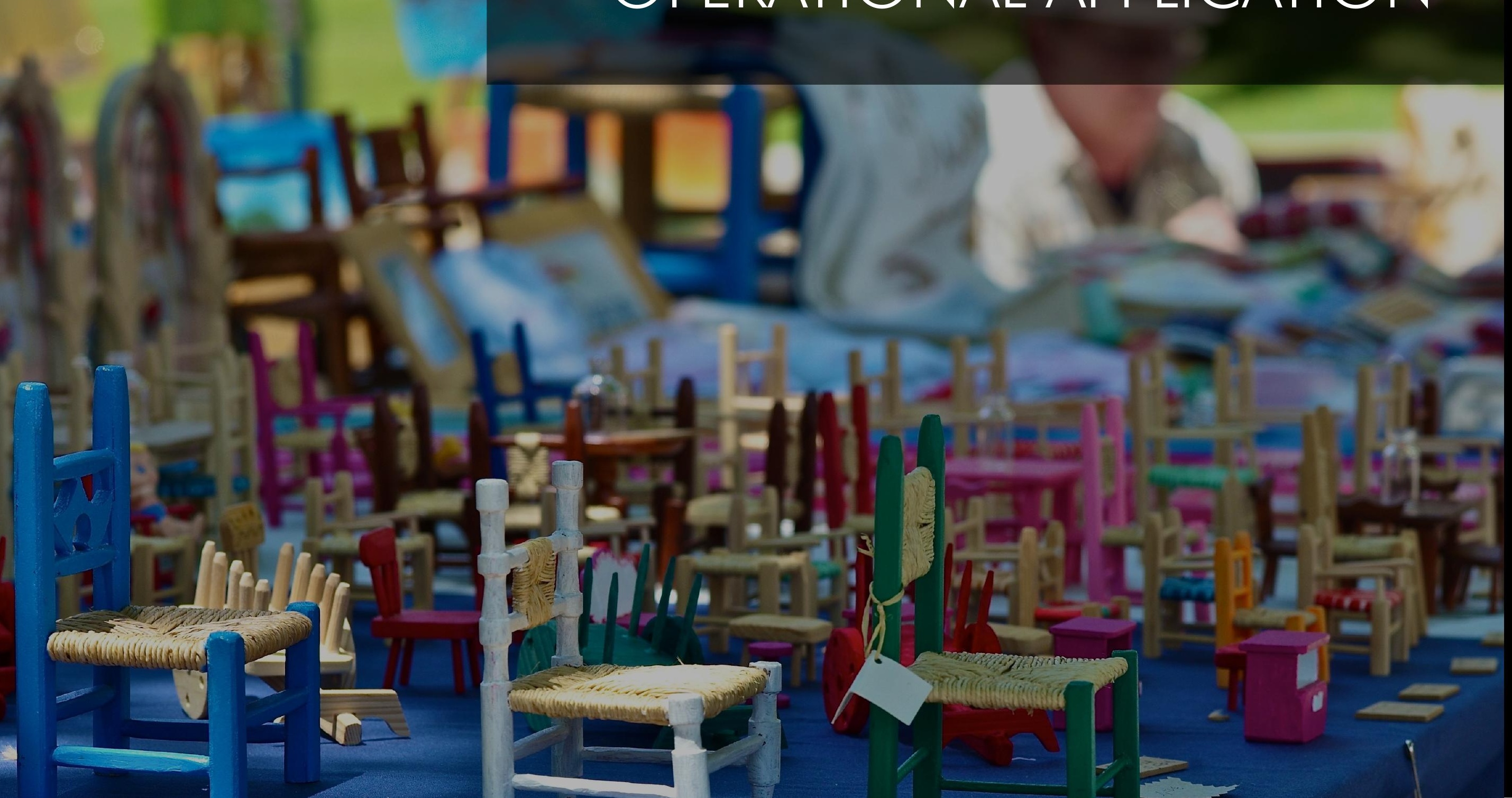




\section{BlackBox Input Tool.}

With the results of each one of the 12 elements

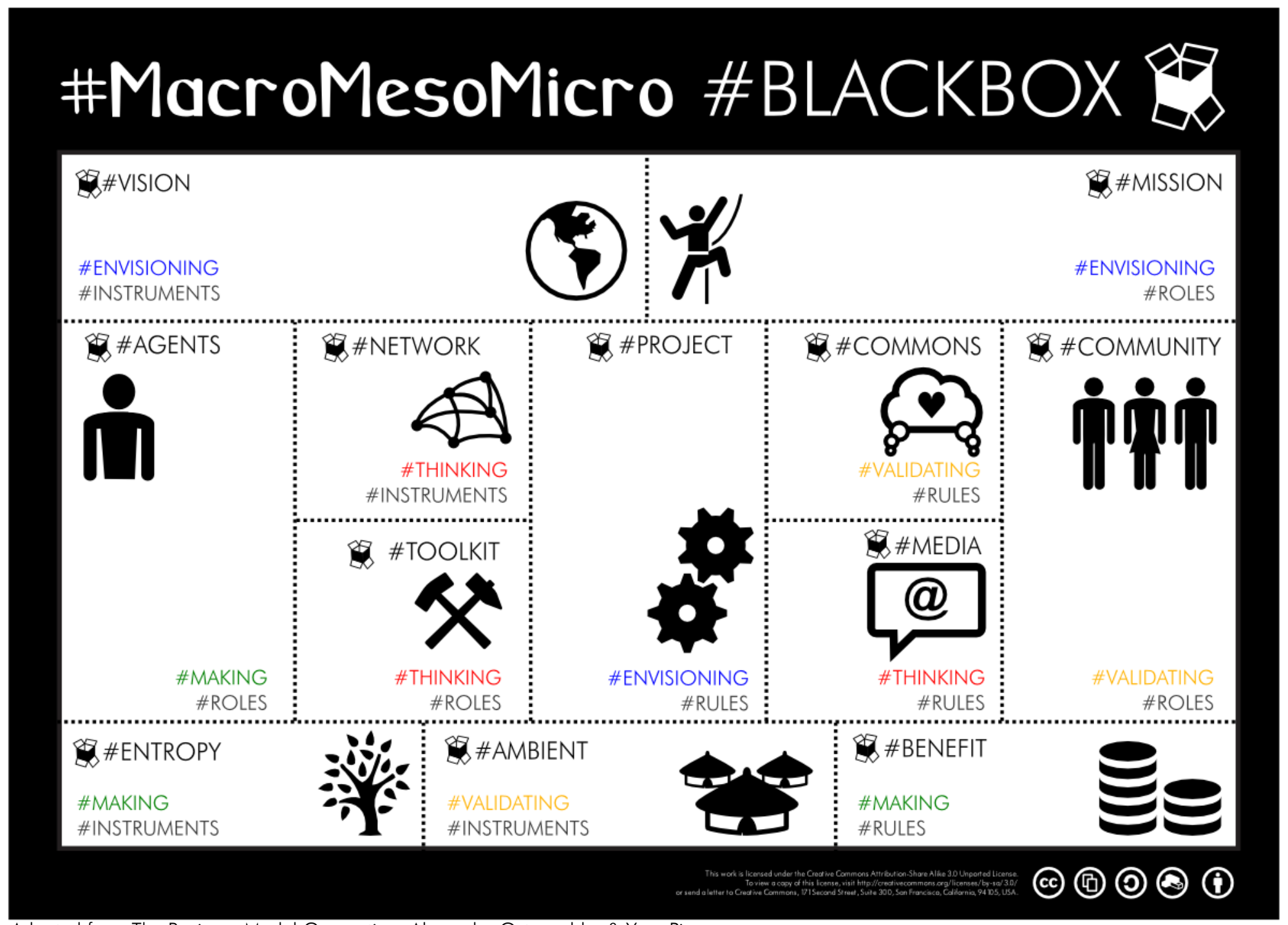

Adapted from The Business Model Generation. Alexander Osterwalder \& Yves Pigneur 


\section{BlackBox Output Tool.}

With the visualisation and measurement of the 12 elements

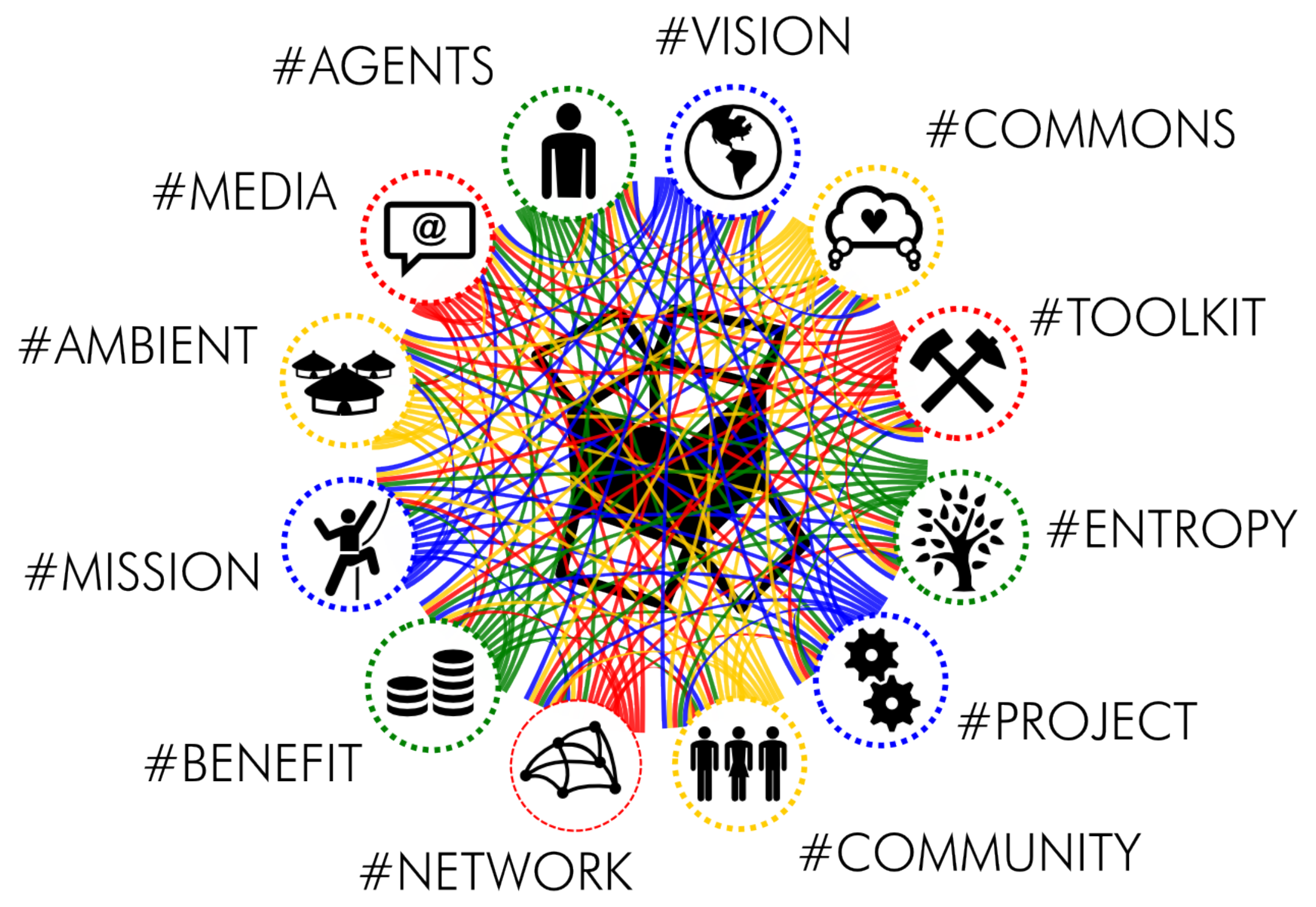




\section{BIBLIOGRAPHICAL REFERENCES.}


Beck, U. (1992), Risk Society: Towards a New Modernity, Sage, London.

Bateson, Gregory (1972), Steps to an ecology of mind: Collected Essays in Anthropology, Psychiatry, Evolution and Epistemology, Jason Aronson, San Francisco. http://www.edtechpost.ca/readings/Gregory\%20Bateson\%20\%20Ecology\%20of\%20Mind.pdf

Bauman, Z, (2003), Comunidad. En busca de seguridad en un mundo hostil. Buenos aires, Siglo XXI, Cap 7.

http://www.teoriasdelaamistad.com.ar/pagina5/Unidad9/3Bauman.pdf

Bauman, Z , (2009), El arte de la vida. Paidos

Bohm, D., (2002), Sobre la Creatividad, Kairós.

Casacuberta, D, (2003), Creación Colectiva, en internet el creador es el público, Gedisa. Barcelona.

Castells, Manuel (2013), Redes de indignación y esperanza,

http://sociologosplebeyos.com/2012/12/19/la-izquierda-ha-desaparecidomanuel-castells

Calzada, I. (201 1a), Towards the Basque City? Comparative Territorial Benchmarking from Social Innovation: Dublin (Ireland) \& Portland (Oregon), Bilbao: Innobasque-Basque Innovation Agency.

Calzada, I. (201 1b), ¿̇Hacia una Ciudad Vasca? Aproximación desde la Innovación Social, Vitoria-Gasteiz: Edit. Servicio Central de Publicaciones del Gobierno Vasco.

Calzada, I. (2005), Cultura, Conocimiento, Innovación y Gestión: Las Clases Creativas en la Euskal Hiria, Vitoria, Revista Vasca de Economía, Ekonomiaz and Euskonews.

Checkland, P, http://www.amazon.com/Systems-Methodology-Action-PeterCheckland/dp/0471986054

Corsín, A,. http://www. prototyping.es

Csikszentmihalyi, M, (1996), Fluir, Una psicología de la felicidad, Kairos.

De Bono, E., (1994), El Pensamiento Creativo. Paidós Plural 
Elden, S., (2013) The Birth of Territory, University of Chicago Press.

Engeström, Y. http://www.helsinki.fi/cradle/activitysystem.htm

Friedman, T. (2005), The World is Flat. Farrar, Straus and Giroux.

Florida, R. (2005), The World is Spiky. Atlantic.

http://www.creativeclass.com/rfcgdb/articles/other-2005-

The\%20World\%20is\%20Spiky.pdf

Gabiña, J. (1998), Prospectiva y ordenación del territorio: Hacia un proyecto de futuro. Marcombo, Barcelona.

Haesbaert, R. (2011), El mito de la desterritorialización: Del "fin de los territorios" a la multiterritorialidad, SigloVentiuno Edit. Madrid.

Hamilton, C. (2010), Requiem for a species: why we resist the truth about climate change, Earthscan, Oxon.

Harvey, D. (2012), El enigma del capital y las crisis del capitalismo, Akal, Madrid.

http://www.academia.edu/694388/Review_of_David_Harveys_The_Enigma_of Capital

Hernández Renner, A, (2012), Un Nuevo Modelo de Desarrollo Local. IDEAZ. Zafra

Herod, A. (201 1), Scale, Routledge, Oxon.

Hall, S. (2012), City, Street and Citizen: The measure of the ordinary,

Routledge, Oxon.

Ibañez, J. (1990), Nuevos avances en la investigación social, Suplementos, $n^{\circ}$ 22. Anthropos.

Innerarity, D. (2012), The Future and Its Enemies, Stanford University Press, California. ISBN: 978-0-8047-7556-4

Innerarity, D. (2013), The Democracy of Knowledge, Bloomsbury Academic, London. ISBN: 978-1-62356-275-5. Pp. 139-183.

Jackson, T. (2009), Prosperity without growth: Economics for a Finite Planet. Earthscan, London.
Johansoon, F. (2006), The Medici Effect, Harvard Business School Press, Boston.

http://cursos.campusvirtualsp.org/pluginfile.php/17603/mod_page/content/2 /Mod2/medicieffect-_2_.pdf

Jones, H. and Gidley, B., (2013), Transnational Soup: Translating Local Integration Policies Across Borders, UCL Geography Urban Salon (20 March 2013), London

Keith, M. (2005), After the Cosmopolitan? Multicultural Cities And The Future of Racism, Routledge, Oxon.

Kotkin, J. (2006) La Ciudad. Una historia global. Debate

Linz, M., Riechmann, J., Sempere, J. (2007) Vivir (bien) con menos. Sobre suficiencia y sostenibilidad. Icaria

Menichinelli, M., (2008), openp2pdesign.org_1.1

http://www.openp2pdesign.org/

Minsky, M., (1986), La Sociedad de la Mente. Galápago. Buenos Aires.

Mintzberg, H., Ahlstrand, B., Lampel, J. (1998), Strategy Safari: A guided tour through the wilds of strategic management, The free press, NY.

Morin, E. (2000) La mente bien ordenada. Seix Barral

Morin, E, Hulot, N. (2008) El año I de la era ecológica. Paidós.

Moulaert, F., MacCallum, D., Mehmood, A. and Hamdouch, A., Calzada, I. (2013), International Handbook of Social Innovation. Social Innovation:

Collective Action, Social Learning and Transdisciplinary Research. Cheltenham: Edward Elgar.

Moulaert, F., et al. (2011) Can Neighbourhoods Save The City? ISBN 978-0415-48588-3. Routledge, Taylor \& Francis Group.

Mulgan, G. (2007), Social Innovation: What it is, why it matters and how it can be accelerated, London, The Basingstoke Press.

Norberg-Schulz, C., (1980), Genius Loci: Towards a Phenomenology of Architecture, Rizzoli. Nueva York.

Nussbaum, M., C., (2012), Crear Capacidades. Paidós. 
Peat, F. D. (2010), Acción Suave. Alternativas innovadoras para un mundo en crisis. Kairos.

Pigem, J, (201 1), GPS. Valores para una sociedad en transformación, Kairós. Pink, D., H., (2007), Una Nueva Mente, www.ilustrae.com

Reig, D, (2012), Socionomía. ¿̇Vas a perderte la revolución social?. Deusto.

Robinson, J., (2006), Ordinary Cities: Between Modernity and Development, Routledge, Oxon.

Robinson, K., (2009), El Elemento. Descubrir tu pasión lo cambia todo, Grijalbo

Rodrigués Villasante, T. (2006). Desbordes creativos. Estilos y estrategias para la transformación social. Los libros de la Catarata.

Thackara, J. (2005), In the Bubble: Designing in a complex world. MIT Press, Sarrionandia, J. http://gara.naiz.info/paperezkoa/20130303/390639/es/Unpueblo-no-va-pareciendo-que-recuerda-que-va-haciendo

Sennet, R. (2012), Together: the rituals, pleasures and politics of cooperation, Penguin London.

Sennet, R. (2009), The Cratsman, Penguin, London.

Shiva, V. (2008) Los monocultivos de la mente. Fineo Editorial.

Subirats, J. (2011), Otra Sociedad ¿Otra Política? De "no nos representan" a la democracia de lo común, Icaria editorial, Barcelona.

Taleb, N., N., (2007), The Black Swan. The Impact of the Highly Improbable, Penguin Books

Tarnas, R, (2006), Cosmos y Psique. Atalanta, Girona.

Williams, R. (1976), Keywords: A vocabulary of culture and society, Oxford University Press, NY

http://graduateglobalissues.files.wordpress.com/2012/08/raymond-williamskeywords.pdf

Yunnus, M, (2011), Las Empresas Sociales. Paidós.

\section{OTHER RESOURCES:}

nounproject.org

Tree designed by Parmelyn from The Noun Project

Coins designed by Mike Hince from The Noun Project

Team designed by Luke Anthony Firth from The Noun Project

Shared Interest designed by Blake Thompson from The Noun Project Mesh Network designed by Lance Weisser from The Noun Project

World designed by Mateo Zlatar from The Noun Project

flickr.com

15M ler Año - II, r2hox, http://www.flickr.com/photos/rh2ox/7178573940/in/faves-60049446@N06/

Net, Mathias Klang,

http://www.flickr.com/photos/wrote/6789379232/in/faves-60049446@N06/

Bokeh, Pedro Ribeiro Simões,

http://www.flickr.com/photos/pedrosimoes7/7278664790/in/faves60049446@N06/

Ball Sculpture, Pedro Ribeiro Simões, http://www.flickr.com/photos/pedrosimoes7/6425940531/in/faves60049446@N06/

Soho, Jon Nicholls, http://www.flickr.com/photos/fotologic/8566075938/in/faves60049446@N06/ 
ABOUT US 


\section{Igor Calzada}

@icalzada | www.igorcalzada.com

Nowadays $(2012<$ ), Dr lgor Calzada (http://about.me/icalzada) is a PostDoctoral Research Fellow at COMPAS \& InSIS, University of Oxford (UK), Programme for the Future of Cities and he is a Fellow at the James Oxford Martin School and Basque

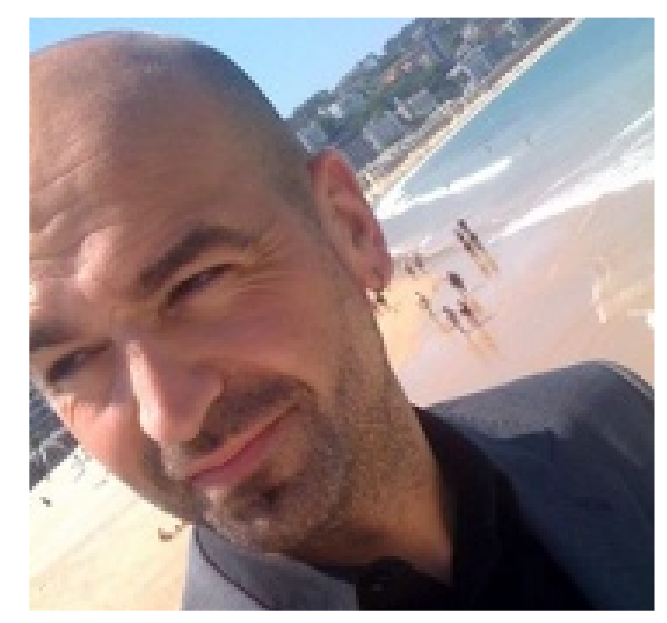
Foundation for Science, Ikerbasque.

He works in basic and applied research projects in the following knowledge fields: Social Innovation applied to Territories \& City-Regions via Action Research Methodologies. He has been directing Congresses, Summer Schools and Workshops, leading basic and applied research projects and publishing books and journal articles in the aforementioned fields. $\mathrm{He}$ is Lecturer \& Research Fellow at the University of Mondragon Unibertsitatea and has been working more than ten years in the Mondragon Co-operative Corporation Group (http://www.mondragon-corporation.com) based in the Basque Country. Last year, 2012, he was the Scientific Director of Future City-Regions/Euskal Hiria 2012 Congress organized by the Basque Government (http://www.basquecity.org \& http://www.euskalhiria.org). He was presented with a Research Award by the Spanish Princess. In 2008, he has been Associate Researcher at the University of Nevada, Reno (USA); in 2009-2010, worked as Director of Research \& Innovation at the Vice-Ministry of the Basque Government; and also has carried out research, on the 5th, 6th and 7th FP of the EU and worked as a Strategic and Innovation Advisor for institutions \& companies. His background is: Urban Sociologist (1997) Dphil at Political Science \& Sociology at the University of Deusto (Spain). Master in Business Administration MBA at the Faculty of Economics \& Business at the University of Deusto (Spain). He obtained the Advanced Studies degree at the University of Helsinki (Finland). He got his PhD at the University of Mondragon, in Territorial Development and Business Administration.

Currently, he is working on his PostDoctoral Research project entitled "Future of CityRegions \& Comparative Territorial Connection" (http://www.cityregions.org), which is an territorial/regional strategies' comparative framework to implement urban transformability and resilience postcrisis socially innovative scalable solutions. Member of the RSA Regional Studies Association, James Oxford Martin School and Basque Studies Society/Eusko Ikaskuntza 


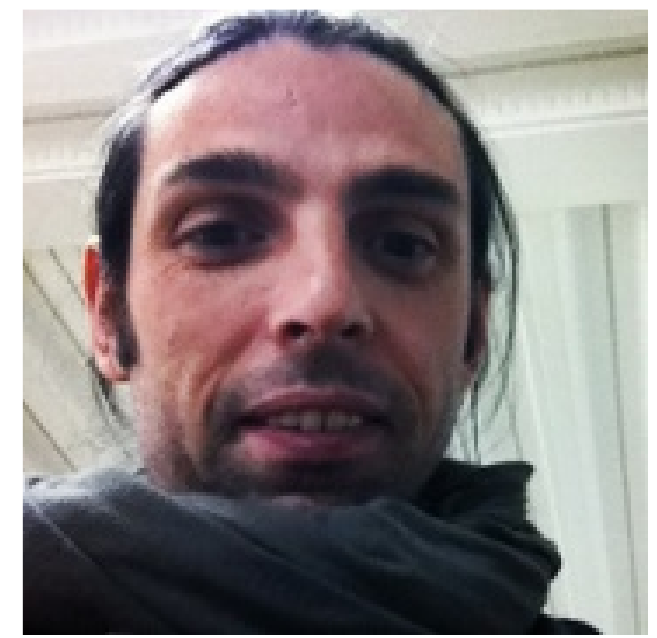

\section{Adolfo Chautón}

@adolfochauton

achauton.tumblr.com

\section{Domenico Di Sieno}

@urbanohumano

urbanohumano.com

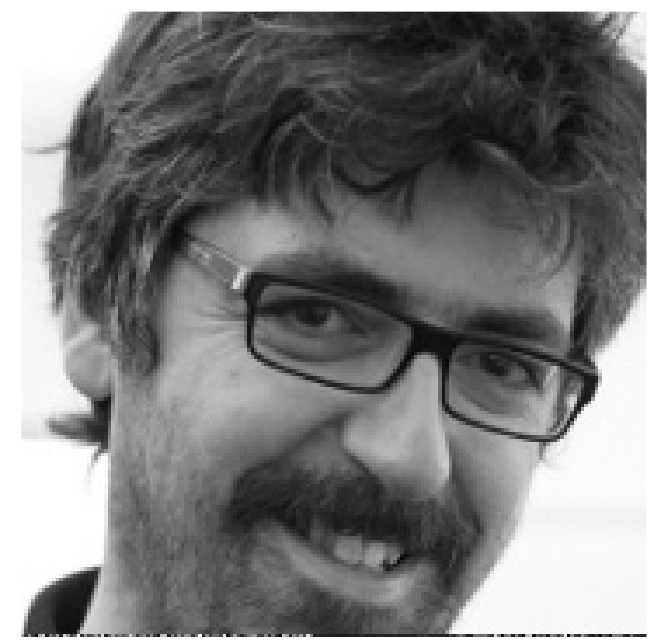

Urban Geographer (2000), degree in Urban and Territorial Planning for the ETSAV (2001) and Masters in Sustainability and LA21 by Univerisity of Extremadura (2003)

His career has been marked by the design and development of open participatory processes projects focused on the user, through action-reflection, hybridizing creativity, technology, sustainability and local development. He has been coordinator of Cáceres Creativa projects (2007-2011) and director of Exterrae, sustainability lab Extremadura (2006-2012) . He was Technical Coordinator of the International Congress "Creative Cities in Imagination Society (2009). He has participated as coordinator or editor in various reports that related creativity and Imagination Society with urban sustainability and local, rural and/or urban development. He had participated in the drafting of territorial urban and strategic planning. He has coordinated and conducted several formative experiences in their work areas.

He now works as independent consultant-researcher-facilitator in the field of Social Innovation and specifically focuses on developing Emprendipia and OpenMandala, an open operating system and a open tool for generating and support projects based on Social Innovation and Entrepreneurship.
Domenico Di Siena is architect, urban planner and researcher; is founder and director of Urbano Humano Agency, Agency for Innovation and Knowledge Society.

Researching and working on possible synergies of physical networks (public space) and digital networks (Internet) for the Urbanism PhD program of the Universidad Politécnica de Madrid where he obtains a DEA degree in 2009.

Experiments and develops hybrid systems to connect architecture and urbanism fields with communication and social media, by new design and management models of urban public space (Sentient City).

Author of the ebook "Sentient City: the City of Knowledge" intellectual synthesis about a new city model based on a technological and social ecosystem.

Curator and co-director of \#OPENmadrid, annual event about Open Design, P2P Urbanism, Social innovation and Sharing Economy in collaboration with the Rey Juan Carlos University.

In 2013 he began the project "Think Cities", a research project and training on Urban Innovation and Territory Management. 